\title{
The Redox Chemistry of Ruthenium Dioxide: A Cyclic Voltammetry Study-Review and Revision
}

\author{
Sebastian Chalupczok (D), Peter Kurzweil (D), Helmut Hartmann, and Christian Schell
}

University of Applied Sciences, Kaiser-Wilhelm-Ring 23, 92224 Amberg, Germany

Correspondence should be addressed to Peter Kurzweil; p.kurzweil@oth-aw.de

Received 30 August 2017; Revised 14 December 2017; Accepted 20 December 2017; Published 1 February 2018

Academic Editor: Gerd-Uwe Flechsig

Copyright (C) 2018 Sebastian Chalupczok et al. This is an open access article distributed under the Creative Commons Attribution License, which permits unrestricted use, distribution, and reproduction in any medium, provided the original work is properly cited.

By cyclic voltammetry at high scan rates, the electrochemical properties of $\mathrm{RuO}_{2}$ in acidic and alkaline solutions were investigated in detail. Thirteen current peaks can be distinguished in sulfuric acid and sodium hydroxide. With respect to the $\mathrm{pH}$ sensitivity of $\mathrm{RuO}_{2}$ electrodes, we considered charge calculations, peak currents, and apparent diffusion coefficients. The nature of the $\mathrm{Ru}(\mathrm{II})$ oxidation was clarified by $\mathrm{Ru}(\mathrm{I})-\mathrm{Ru}(\mathrm{III})$ species.

\section{Introduction}

The redox activity of platinum metal oxides has been considered for electrolysis, electrochemical storage devices, and $\mathrm{pH}$ sensors [1-4]. Ruthenium dioxide electrodes have been studied since the early 1970 s because of the mixed electronic and ionic conductivity $(35.2 \pm 0.5 \mu \Omega \cdot \mathrm{cm})$ [5]. Despite many attempts, the mechanisms of the electrochemical processes on a $\mathrm{RuO}_{2}$ electrode in acidic and alkaline solutions, as well as in organic solvents, are not fully understood. Since the $\mathrm{RuO}_{2}$ /solution interface behaves like an electric capacitor, that can be charged and discharged very quickly, we employ cyclic voltammetry $[6,7]$ for in-depth analysis of the redox processes in the electrode surface.

This paper considers the electrochemical behavior of thermally produced $\mathrm{RuO}_{2}$ electrodes in acidic and alkaline solutions with special respect to the oxygen (OER) and hydrogen evolution reactions (HER) in different solutions.

\section{Experimental}

2.1. Preparation of Electrodes. Electrodes were prepared by thermal decomposition of commercial-grade ruthenium(III) chloride hydrate (Sigma-Aldrich) on titanium supports (thermal spray pyrolysis).

$$
\begin{aligned}
& 2\left(\mathrm{RuCl}_{3} \cdot 3 \mathrm{H}_{2} \mathrm{O}\right)+\frac{1}{2} \mathrm{O}_{2} \\
& \quad \rightleftharpoons 2\left(\mathrm{RuO}_{2} \cdot 1.5 \mathrm{H}_{2} \mathrm{O}\right)+6 \mathrm{HCl}
\end{aligned}
$$

The oxide formation takes place at a temperature of about $360^{\circ} \mathrm{C}[8]$, which was verified by thermogravimetric analysis using a Netzsch 209 F1 Libra (TGA) in a platinum-rhodium crucible under oxygen atmosphere (Figure 1). The mass change is determined by the evaporation of both adsorbed water and crystal water and the formation of the oxide phase.

To ensure good adhesion on titanium (thickness $0.050 \mathrm{~mm}$, Ankuro Int. $\mathrm{GmbH}$ ), the substrate was roughened and degreased with acetone. Then a slurry of $\mathrm{RuCl}_{3} \cdot x \mathrm{H}_{2} \mathrm{O}$ in acetone was applied to the substrate which was clamped in a coating frame with sealed recesses. After drying overnight, the heat treatment was carried out in a furnace in air at $500^{\circ} \mathrm{C}$ for $2 \mathrm{~h}$. The mass of the resulting $d=2 \mu \mathrm{m}$ thick $\mathrm{RuO}_{2}$ layer was $m / A=8.0 \mathrm{mg} \mathrm{cm}^{-2}$ (electrode area: $1 \mathrm{~cm}^{2}$ ). According to $\varrho d=m / A$, the calculated density equals $\varrho=$ $4 \mathrm{~g} \mathrm{~cm}^{-3}$, which suggests a porosity of $57 \%$ with respect to the theoretical density of compact $\mathrm{RuO}_{2}\left(7 \mathrm{~g} \mathrm{~cm}^{-3}\right)$. Zinc ion adsorption measurements of Savinell et al. [9] suggest 14.6 $\pm 1.6 \mathrm{~cm}^{2} \mathrm{mg}^{-1}\left(\mathrm{Ti} \mid \mathrm{RuO}_{2}\right.$, annealed at $450^{\circ} \mathrm{C}$ for $\left.1 \mathrm{~h}\right)$. Hence, the electrochemically active surface amounts to $100-120 \mathrm{~cm}^{2}$. Impedance spectra confirm a capacitance of about $4 \mathrm{mF} \mathrm{cm}^{-2}$ 


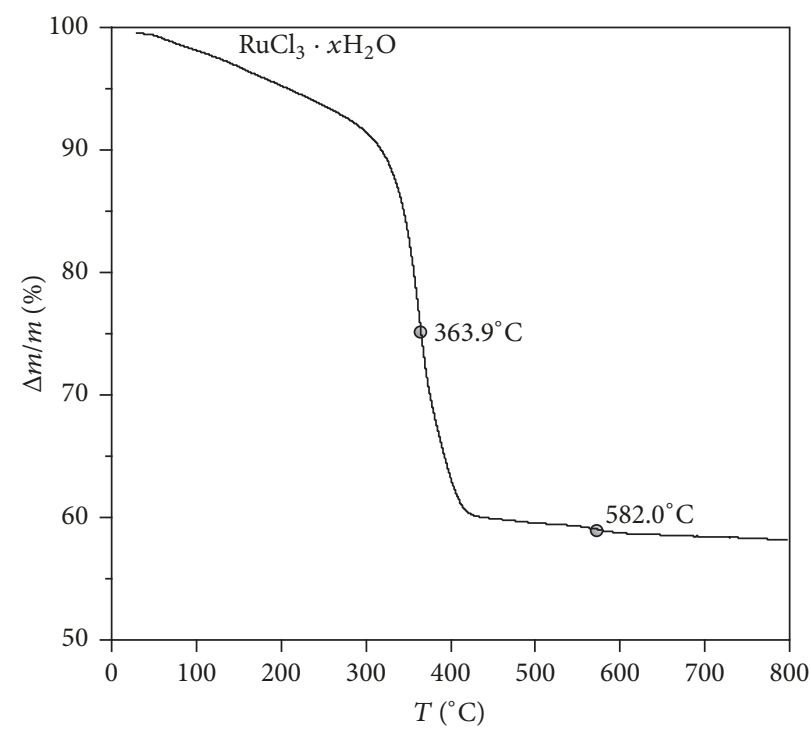

FIGURE 1: Thermogravimetric analysis of ruthenium chloride.
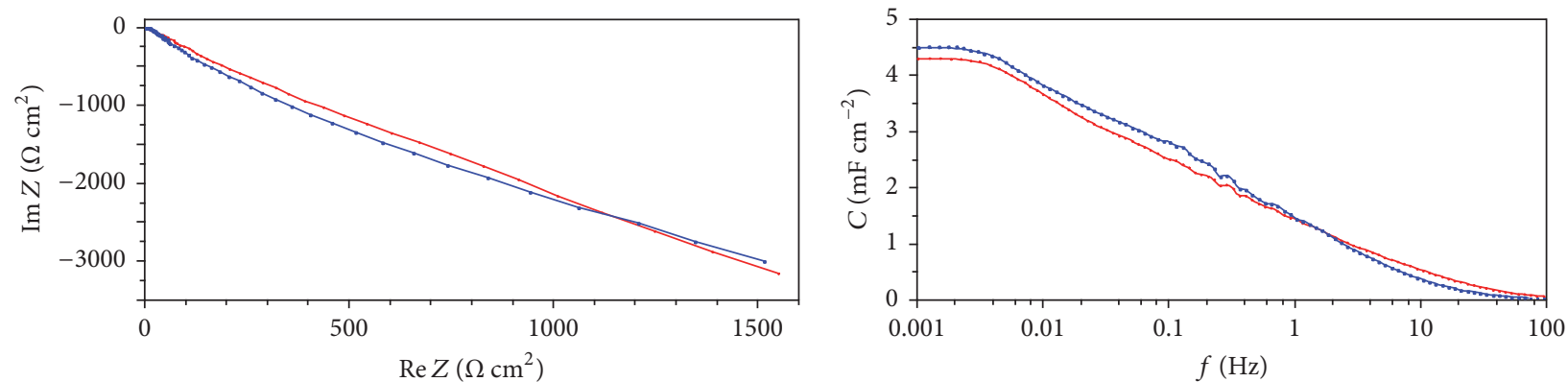

FIGURE 2: Complex plane plot of impedance and frequency response of capacitance of a cell of two identical RuO $/$ Ti electrodes in 1-molar sulfuric acid (red) and 1-molar sodium hydroxide solution (blue). Capacitance calculated for single electrode, $C(\omega)=0.5 \cdot[-\omega \operatorname{Im} \underline{Z}(\omega)]^{-1}$.

$\left(0.4 \mathrm{~F}\right.$ per real $\left.\mathrm{cm}^{2}\right)$ in aqueous solution (Figure 2). The BET surface of thermal $\mathrm{RuO}_{2}$ powders (roughly $100 \mathrm{~m}^{2} \mathrm{~g}^{-1}$ ) drops with heat treatment to less than $10 \mathrm{~m}^{2} \mathrm{~g}^{-1}$ due to sintering of the particles.

2.2. Instruments and Methods. Cyclic voltammetry was carried out with a three-electrode arrangement using a potentiostat/galvanostat (EC301, Stanford Research Systems, Inc.). A reversible hydrogen electrode (RHE) was used as the reference electrode, and a platinum sheet $\left(12 \mathrm{~cm}^{2}\right)$ as the counterelectrode. All measurements employed $1 \mathrm{M} \mathrm{H}_{2} \mathrm{SO}_{4}$ or $1 \mathrm{M} \mathrm{NaOH}$ at a constant temperature of $25 \pm 0.5^{\circ} \mathrm{C}$. The $\mathrm{RuO}_{2}$ powder was characterized by X-ray diffraction (XRD, Rigaku Miniflex 600) and SEM/EDX (Stereoscan LEO 440).

\section{Results and Discussion}

3.1. Characterization of Electrodes. Figure 3 compiles the $\mathrm{X}-$ ray diffractograms of $\mathrm{RuO}_{2}$, prepared by thermal decomposition of $\mathrm{RuCl}_{3} \cdot x \mathrm{H}_{2} \mathrm{O}$ at different temperatures. As confirmation of the thermogravimetric analysis, the generation of the

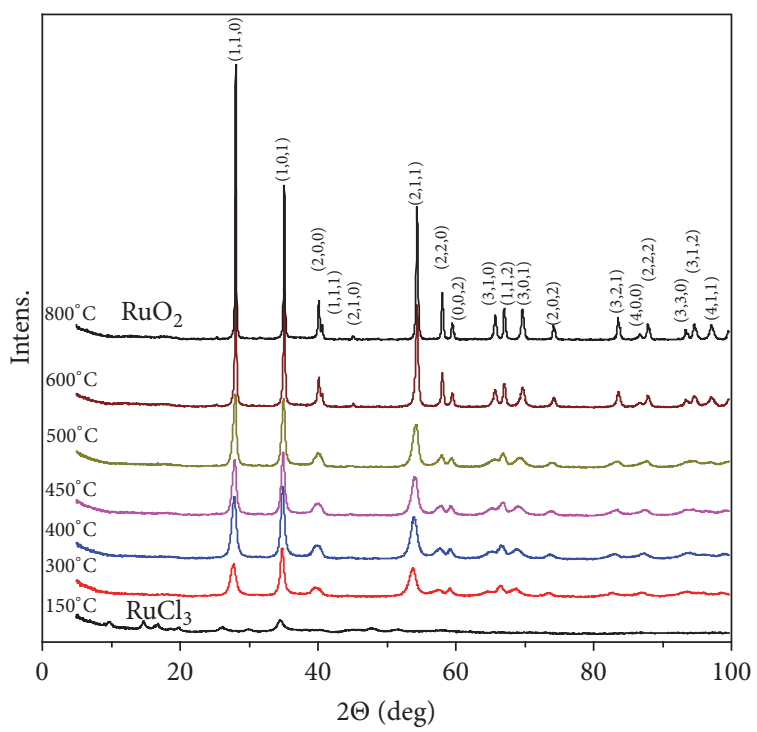

FIGURE 3: XRD measurements of the thermally decomposed $\mathrm{RuCl}_{3}$ hydrate to $\mathrm{RuO}_{2}$ by annealing with different temperatures. 


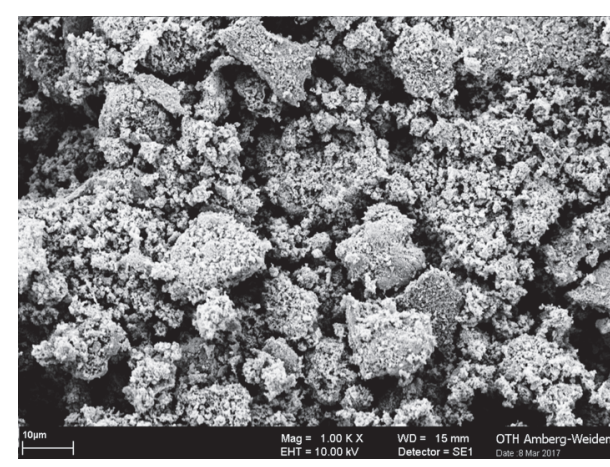

(a)

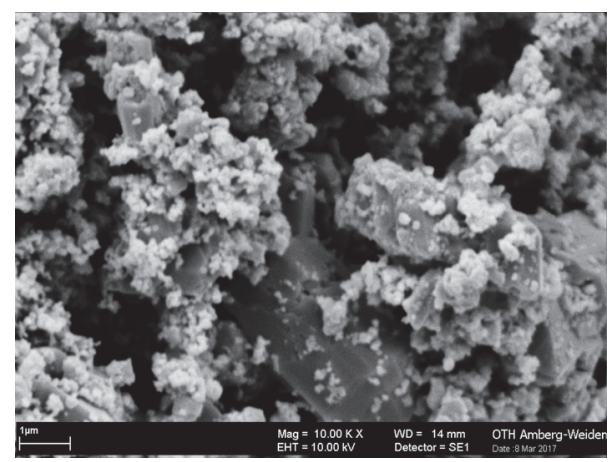

(c)

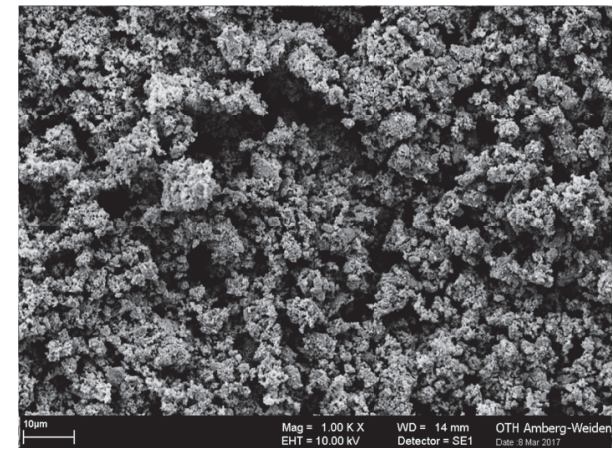

(b)

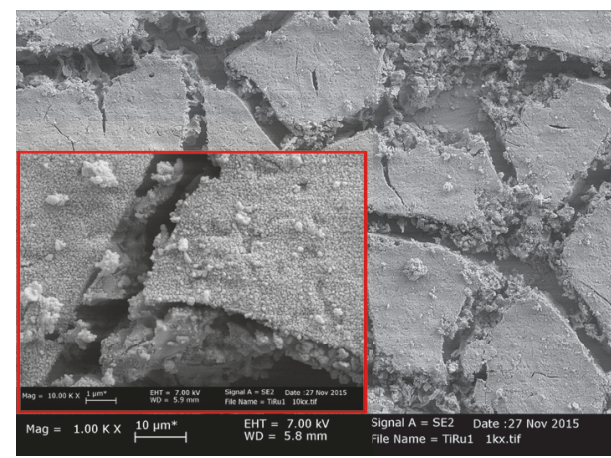

(d)

Figure 4: SEM images of $\mathrm{RuO}_{2}$ prepared at (a) $300^{\circ} \mathrm{C}, 1000$-fold magnification, (b) $600^{\circ} \mathrm{C}, 1000 \mathrm{x},(\mathrm{c}) 600^{\circ} \mathrm{C}, 10000 \mathrm{x}$; (d) $\mathrm{RuO} 2$ coated on titanium by thermal spray pyrolysis at $500^{\circ} \mathrm{C}(1000 \mathrm{x})$, insert at 10000 -fold magnification.

oxide is obvious to take place at temperatures between $300^{\circ} \mathrm{C}$ and $400^{\circ} \mathrm{C}$

Below $300^{\circ} \mathrm{C}$, amorphous $\mathrm{RuO}_{2} \cdot x \mathrm{H}_{2} \mathrm{O}$ is received, which contains a residual chloride. The diffraction peaks at $2 \Theta<28^{\circ}$ were attributed to chloride. Above $300^{\circ} \mathrm{C}$, the rutile structure of crystalline $\mathrm{RuO}_{2}$ appears more and more; the crystal system is tetragonal.

The main peak at about $2 \Theta=28^{\circ}$ belongs to (110), and (101) occurs at $2 \Theta=35^{\circ}$. With rising temperature, the full width at half maximum (FWHM) drops as the diffraction peaks become sharper. Additionally, further lattice planes are formed. According to the Debye-Scherrer equation, the average size of the crystallites was calculated:

$$
d=\frac{K \lambda}{\operatorname{FWHM}(2 \Theta) \cdot \cos (\Theta)},
$$

wherein $d$ is the particle size in $\mathrm{nm}, \lambda$ is the $\mathrm{X}$-ray wavelength ( $\AA$ or pm), $K$ is a shape factor, and $\Theta$ is the Bragg angle. At $500^{\circ} \mathrm{C}$, the calculated particle size is approximately $14.7 \mathrm{~nm}$ (110) and $15.6 \mathrm{~nm}$ (101), respectively. The lattice constants at $500^{\circ} \mathrm{C}$ read the following: $a=b=450.4 \mathrm{pm}$ and $c=311.5 \mathrm{pm}$.

Most of the ruthenium and oxygen atoms in the bulk material are present in the crystal orientations (110) and (101), whereas (101), (111), and (100) exist predominantly on the material surface [10]. Hence, the electrochemical properties of polycrystalline $\mathrm{RuO}_{2}$ are determined by the (110) face.
The rutile structure of stoichiometric $\mathrm{RuO}_{2}$ (110) [11] consists of a slightly distorted octahedron with 4 equatorial and 2 apical $\mathrm{Ru}-\mathrm{O}$ directions. On the surface, bridging oxygen atoms are coordinated with two $\mathrm{Ru}$ atoms underneath, and a $\mathrm{Ru}$ atom on a onefold coordinatively unsaturated site is coordinated with five oxygen atoms [12].

The SEM/EDX measurements (Figure 4) show the microporous powder morphology of $\mathrm{RuO}_{2}$ and the unavoidable content of chlorine (about 5\%) that is caused by thermolysis of the $\mathrm{RuCl}_{3}$ precursor. Our previous TOF-SIMS study [13] showed residual chlorine bound in $\mathrm{Ru}-\mathrm{O}-\mathrm{Cl}$ clusters. Although the EDX analysis gives only a rough estimate of the surface, because of the limited penetration depth of the Xrays, some surplus of oxygen beyond the formula $\mathrm{RuO}_{2}$ was observed. This is partly due to adsorbed and bound water, especially as some three-valent ruthenium is present at the surface in compositions up to $\mathrm{Ru}(\mathrm{OH})_{3}$.

The $\mathrm{RuO}_{2}$ layer reveals an undesired particle agglomeration due to the thermal treatment at $600^{\circ} \mathrm{C}$. In contrast to that, the $300^{\circ} \mathrm{C}$ powder exhibits particle sizes of approximately 17.8 $\pm 2.9 \mu \mathrm{m}$, and a porous structure around an average pore size of $1.4 \pm 0.5 \mu \mathrm{m}$. At $600^{\circ} \mathrm{C}$ the particle size is about 8.6 $\pm 2.3 \mu \mathrm{m}$, and the pore widths decrease to $0.87 \pm 0.3 \mu \mathrm{m}$. In particular, some small particles of the size $0.75 \pm 0.4 \mu \mathrm{m}$ adhere forming agglomerates.

Over et al. [14] showed that an ultrathin $\mathrm{RuO}_{2}$ (110) film can be formed on ruthenium exposed to oxygen. Once a 


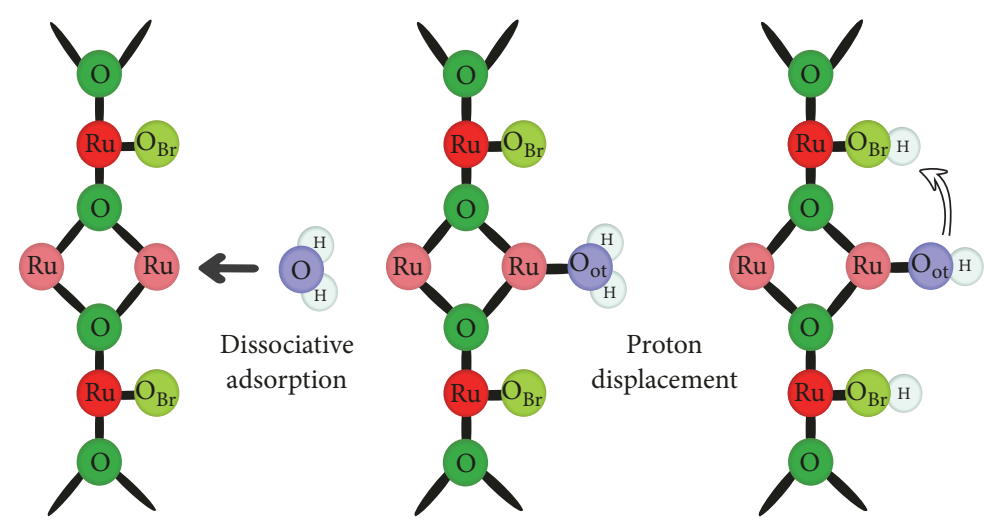

FIGURE 5: Mechanism of the dissociative adsorption of water and proton displacement during anodic charging of $\mathrm{RuO}_{2}$ (this work based on $[1,4,10,12])$.

nucleus has formed, it grows autocatalytically forming large domains of $\mathrm{RuO}_{2}$ (110). Oxide growth is limited by the mass transport of oxygen and metal ions across the oxide film.

Furthermore, ruthenium is able to incorporate dissolved oxygen into the basal plane $[15,16]$. In the SEM image (Figure $4(\mathrm{~d})$ ), $\mathrm{RuO}_{2}$ coated on titanium shows a fissured surface around sponge-like areas of approximately $43 \pm$ $14 \mu \mathrm{m}$. The pimpled nanostructure is made up of particle sizes of $0.1 \pm 0.03 \mu \mathrm{m}$, and the vacancies between these particles are approximately $0.03 \pm 0.01 \mu \mathrm{m}$. The cracks, caused by the evaporation of the solvent, are about $4.6 \pm 1.0 \mu \mathrm{m}$ wide. The inserted magnification shows the bright nanoparticles $(0.61$ $\pm 0.4 \mu \mathrm{m})$ described above. The above results confirm the extraordinarily porous structure of thermally prepared $\mathrm{RuO}_{2}$.

3.2. Mechanism of Water Adsorption. The $\mathrm{RuO}_{2}$ surface is covered by a carpet of $\mathrm{OH}$ groups due to the dissociative adsorption of water followed by proton displacement [1]. Bridged oxygen is seldom the preferred adsorption site for most molecules, but it is relevant to hydrogen adsorption which results in $\mathrm{OH}$ groups with bridged $\mathrm{O}$ atoms [12]. Two sorts of hydroxyl groups are formed during anodic charging: $\mathrm{O}_{\mathrm{Br}} \mathrm{H}$ with bridged oxygen and $\mathrm{O}_{\mathrm{ot}} \mathrm{H}$, which exists only on onefold coordinatively unsaturated $\mathrm{Ru}$ atoms; see Figure 5. The $\mathrm{Ru}$ atom acts as a Lewis acid/base (electron acceptor), whereas $\mathrm{O}_{\mathrm{Br}}$ is a Brønsted base (proton acceptor).

Due to the dissociative adsorption of water, protons (or hydroxide sites) from the surrounding electrolyte can penetrate into the porous electrode. The proton exchange between $\mathrm{RuO}_{2}$ surface and aqueous solution reads as follows [1]:

$$
\mathrm{RuO}_{x}(\mathrm{OH})_{y}+z \mathrm{e}^{-}+z \mathrm{H}^{+} \rightleftharpoons \mathrm{RuO}_{x-z}(\mathrm{OH})_{y+z}
$$

Simplified: $\mathrm{Ru}^{\mathrm{IV}} \mathrm{O}_{2}+\mathrm{e}^{-}+\mathrm{H}^{+} \rightleftharpoons \mathrm{Ru}^{\mathrm{III}} \mathrm{O}(\mathrm{OH})$

According to Nernst's equation the redox potential of the $\mathrm{RuO}_{2}$ electrode depends on the $\mathrm{pH}$ value:

$$
\begin{aligned}
& E=E^{0}-\frac{\mathrm{RT}}{F} \ln \frac{c\left(\mathrm{Ru}^{\mathrm{III}}\right)}{c\left(\mathrm{Ru}^{\mathrm{IV}}\right) \cdot c\left(\mathrm{H}^{+}\right)}=E^{0} \\
& -\frac{\ln 10 \cdot \mathrm{RT}}{F}\left(\mathrm{pH}+\log \frac{c\left(\mathrm{Ru}^{\mathrm{III}}\right)}{c\left(\mathrm{Ru}^{\mathrm{IV}}\right)}\right) \\
& \left(25^{\circ} \mathrm{C}\right) \quad E=E^{0}-0.059 \mathrm{~V} \cdot \mathrm{pH}
\end{aligned}
$$

whereby the thermodynamically calculated standard potential (versus the SHE) equals $E^{0}=0.94 \mathrm{~V}$ [17].

3.3. Electrochemistry in Acidic Solution. The cyclic voltammograms at rates up to $4000 \mathrm{mV} / \mathrm{s}$ reveal more than ten different peaks; see Figure 6. The open circuit potential (OCP) of $\mathrm{RuO}_{2}$ in 1-molar $\mathrm{H}_{2} \mathrm{SO}_{4}$ was $0.92 \mathrm{~V}$, in good agreement with the calculated standard potential and results of other authors (range 0.90-0.95 V) [3]. At the OCP, there is an equilibrium of $\mathrm{Ru}(\mathrm{IV})$ and $\mathrm{Ru}(\mathrm{III})$. The region $0-0.4 \mathrm{~V}$ can be attributed to the hydrogen sorption, which is also known from platinum [18]. As well, at $\mathrm{RuO}_{2}$ single crystals, Hepel and coworkers [10] attributed the two peaks at $0 \mathrm{~V}$ and $0.24 \mathrm{~V}$ in $0.5 \mathrm{M} \mathrm{H}_{2} \mathrm{SO}_{4}$ to the hydrogen adsorption on the surfaces (110) and (001). The cathodic reduction of $\mathrm{RuO}_{2}$ to metallic ruthenium does not occur during cyclic voltammetry, in contrast to the platinum electrode. This was verified by SEM/EDX results which do not show any metallic ruthenium on the support.

According to the mechanism in Figure 5, the anodic peak 1 at about $26 \pm 15 \mathrm{mV}$ in $1 \mathrm{M} \mathrm{H}_{2} \mathrm{SO}_{4}$ reflects the hydrogen adsorption on the onefold coordinatively unsaturated $\mathrm{Ru}$ atom.

If oxygen is present, which is the case for (110) surfaces, the second peak 2 at $143 \pm 9 \mathrm{mV}$ is most likely due to the hydrogen adsorption at oxygen. Hepel and coworkers [10] describe the hydrogen oxidation peaks as follows:

$$
\begin{aligned}
& \text { Peak 1: } \mathrm{H}_{3} \mathrm{O}^{+}+\overline{\mathrm{Ru}}+\mathrm{e}^{-} \rightleftharpoons \overline{\mathrm{Ru}} \cdot \mathrm{H}+\mathrm{H}_{2} \mathrm{O} \\
& \text { Peak 2: } \mathrm{H}_{3} \mathrm{O}^{+}+\overline{\mathrm{O}}+\mathrm{e}^{-} \rightleftharpoons \overline{\mathrm{O}} \cdot \mathrm{H}+\mathrm{H}_{2} \mathrm{O}
\end{aligned}
$$




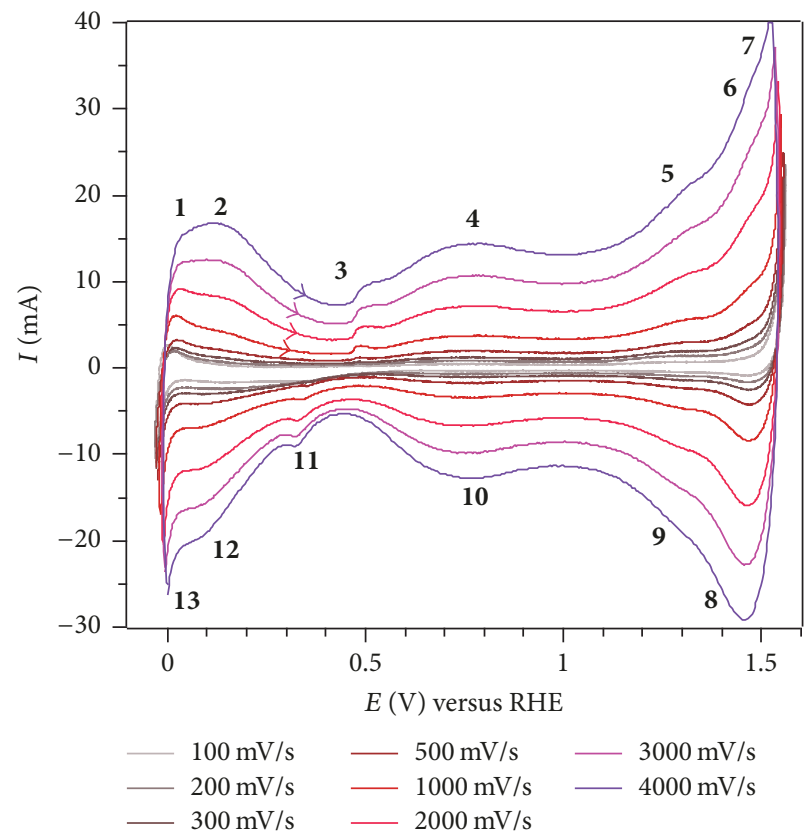

Figure 6: Cyclic voltammograms of a Ti/ $\mathrm{RuO}_{2}$ electrode in 1-molar $\mathrm{H}_{2} \mathrm{SO}_{4}$ ( $\mathrm{pH} 0.08$ ) at $25^{\circ} \mathrm{C}$ at different scan rates; $2 \mathrm{nd}$ cycle. Counterelectrode: platinum sheet. The electrolyte resistance $\left(R_{e}=1.8 \Omega\right)$ was corrected. Arrows: oxidation wave in anodic direction. Reference electrode: reversible hydrogen electrode: $V$ RHE $=V$ SHE $-0.059 \mathrm{pH}$.

The reduction peak 12 at $75 \pm 24 \mathrm{mV}$ (and a previous shoulder at $247 \pm 13 \mathrm{mV}$ ) reflects the hydrogen sorption at $\mathrm{RuO}_{2}$ that can already be seen at moderate scan rates of $100-200 \mathrm{mV} / \mathrm{s}$ and includes chemical and electrochemical steps. Peak $\underline{3}$ at about $490 \pm 12 \mathrm{mV}$ either may be due to the preparation of the electrode and is typical for measurements in concentrated solutions; if the 1-molar sulfuric acid is diluted to 0.1 molar, the peak disappears. The reduction peak $\underline{11}$ corresponds at about $333 \pm 14 \mathrm{mV}$. Doblhofer et al. [3] speculated that $\mathrm{Ru}$ (II) might be present in the hydrogen region. We suggest that $\mathrm{Ru}(\mathrm{II})$ might be a mixed $\mathrm{Ru}(\mathrm{I})-\mathrm{Ru}(\mathrm{III})$ species in a cluster ion. The assumption of $\mathrm{Ru}(\mathrm{III})$ at $400 \mathrm{mV}$ is in good agreement with thermodynamic data that the conversion of $\mathrm{Ru}$ (III) to $\mathrm{Ru}(\mathrm{IV})$ takes place within $0.4-1.0 \mathrm{~V}$. That supports the theory that any unstable oxide, only stable in highly conductive acids, might be formed in the course of the rearrangement of surface oxides. Peak 4 reflects the $\mathrm{Ru}(\mathrm{III}) / \mathrm{Ru}(\mathrm{IV})$ redox couple at about $756 \pm 11 \mathrm{mV}$ and the reduction peak 10 at about $744 \pm 16 \mathrm{mV}$. Michell et al. [19] confirm $780 \mathrm{mV}$, and $750 \mathrm{mV}$ was found by Doblhofer et al.

$$
\text { Peak ㄴ: } 2 \mathrm{RuO}_{2}+2 \mathrm{H}^{+}+2 \mathrm{e}^{-} \rightleftharpoons \mathrm{Ru}_{2} \mathrm{O}_{3}+\mathrm{H}_{2} \mathrm{O}
$$

Modified notations of (9) consider that $\mathrm{Ru}$ (III) can be written as $2 \mathrm{Ru}(\mathrm{OH})_{3} \equiv \mathrm{Ru}_{2} \mathrm{O}_{3} \cdot 3 \mathrm{H}_{2} \mathrm{O} \equiv 2 \mathrm{RuO}(\mathrm{OH})+2 \mathrm{H}_{2} \mathrm{O}$, which leads back to (4). Anyway, the number of exchanged protons per ruthenium atom equals $z=1$. The interesting fact is the $\mathrm{pH}$ dependence of the equilibrium potential that can be used for a potentiometric $\mathrm{pH}$ sensor [1]. A screen printed $\mathrm{RuO}_{2}$ electrode on polyester film (versus a saturated calomel reference) reveals a sensitivity of $-51.2 \mathrm{mV} / \mathrm{pH}$ ( $\mathrm{pH} 2-9$ ), but unfortunately it shows a potential drift due to continuous corrosion [20].
A screen printed $\mathrm{RuO}_{2} / \mathrm{Ta}_{2} \mathrm{O}_{5}$ electrode $(70: 30 \mathrm{wt} \%)$ achieved $-56 \mathrm{mV} / \mathrm{pH}$ versus $\mathrm{Ag} \mid \mathrm{AgCl}(\mathrm{pH} 2-12)$. So far, all $\mathrm{pH}$ sensors based on metal oxides suffer from hysteresis effects and interferences [21].

Galizzioli et al. [22] concluded that roughly $6-7 \%$ of the $\mathrm{RuO}_{2}$ particles are able to participate in the reaction and pointed to the oxygen deficiency stoichiometry of the oxide. High annealing temperatures and oxygen atmosphere lead to less $\mathrm{Ru}(\mathrm{III})$, and the amorphous regions give way to crystalline oxide.

Peak $\underline{5}$ at $1286 \pm 15 \mathrm{mV}$ follows the continuous oxidation of the $\mathrm{RuO}_{2}$ and might be attributed either (i) to a transition state followed by further oxidation to $\mathrm{Ru}(\mathrm{V})$ [3] or (ii) to $\mathrm{Ru}(\mathrm{VI})$ as suggested by Burke et al. [23-25]. Whereas $\mathrm{Ru}(\mathrm{V})$ is considered to be instable, the existence of $\mathrm{Ru}(\mathrm{VI})$ was proved by XPS studies, $\mathrm{RuO}_{2}$ prepared by $\mathrm{RuCl}_{3}$ thermolysis. $\mathrm{Ru}(\mathrm{VI})$ should be stable during anodic polarization in $1 \mathrm{M} \mathrm{H}_{2} \mathrm{SO}_{4}$ [26]. Recent thermodynamic calculations for ruthenium in aqueous solutions at different $\mathrm{pH}$ postulate solid ruthenium(V) oxide [27], having the standard electrode potential $E^{0}=1.222 \mathrm{~V}$ (at $\left.1.94<\mathrm{pH}<2.55\right)$. This is in excellent agreement with our peak at $1286 \pm 15 \mathrm{mV}$, corrected by one $\mathrm{pH}$ step. The corresponding reduction peak $\underline{9}$ occurs at 1284 $\pm 19 \mathrm{mV}$.

$$
\begin{gathered}
\text { Peak } \underline{5}: \frac{1}{2} \mathrm{Ru}_{2} \mathrm{O}_{5(\mathrm{~s})}+3 \mathrm{H}^{+}+\mathrm{e}^{-} \\
\rightleftharpoons \mathrm{Ru}(\mathrm{OH})_{2}{ }^{2+}+\frac{1}{2} \mathrm{H}_{2} \mathrm{O}
\end{gathered}
$$

Peak $\underline{6}$ at about $1441 \pm 4 \mathrm{mV}$ and its reduction $\underline{8}$ at 1463 $\pm 4 \mathrm{mV}$ in acidic solution correspond to thermodynamic 


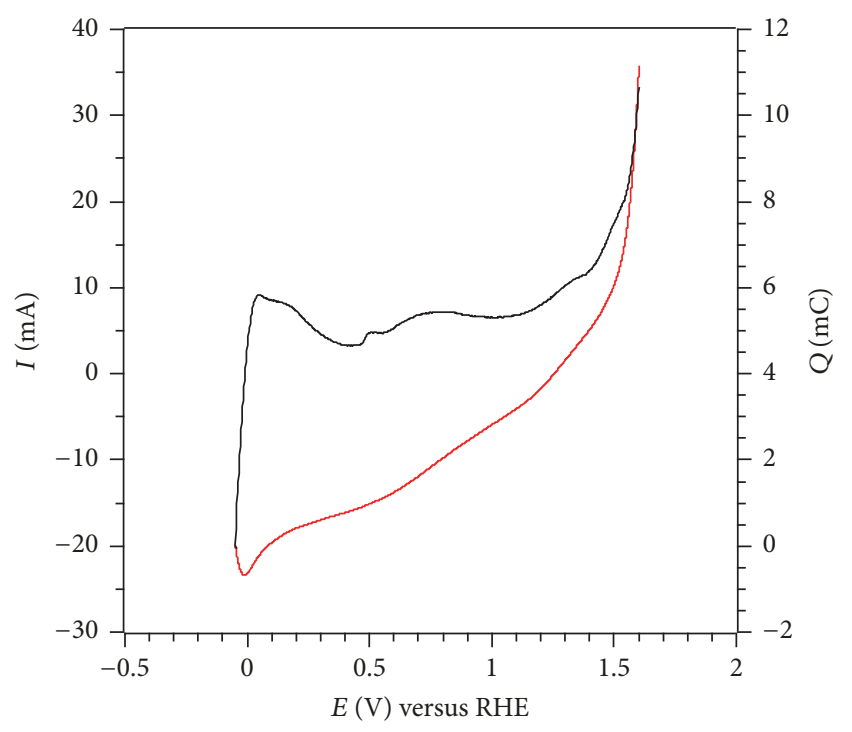

Figure 7: Anodic potential sweep and electric charge (red) of a $\mathrm{RuO}_{2} /$ Ti electrode at $2000 \mathrm{mV} / \mathrm{s}$ in $1 \mathrm{M} \mathrm{H}_{2} \mathrm{SO}_{4}\left(25^{\circ} \mathrm{C}\right)$.

calculations of $\mathrm{Ru}(\mathrm{VIII})$ in the range $1.94<\mathrm{pH}<5.94$ at a standard the potential $E^{0}=1.466 \mathrm{~V}$ [27].

$$
\text { Peak } \underline{6}: \mathrm{H}_{2} \mathrm{RuO}_{5}+3 \mathrm{H}^{+}+3 \mathrm{e}^{-} \rightleftharpoons \frac{1}{2} \mathrm{Ru}_{2} \mathrm{O}_{5(\mathrm{~s})}+\frac{5}{2} \mathrm{H}_{2} \mathrm{O}
$$

Further oxidation ( $>1.4 \mathrm{~V}$ RHE) results in the dissolution of ruthenium oxide as $\mathrm{H}_{2} \mathrm{RuO}_{5} \rightarrow \mathrm{RuO}_{4}+\mathrm{H}_{2} \mathrm{O}$, which is a known corrosion product during violent electrolytic oxygen evolution $[28,29]$. At Peak 7 (about $1.6 \mathrm{~V}$ ) the oxygen evolution reactions start.

3.3.1. Electrochemical Valency. In order to distinguish between reversible and irreversible electron transfer, the redox peaks were evaluated with respect to peak current, potential, and electric charge. According to the theory of cyclic voltammetry, the potential difference is about $59 \mathrm{mV}$ between the oxidation peak and the reduction peak of a totally reversible electron transfer. The peak currents for a reversible electron transfer should be identical.

$$
\begin{aligned}
\Delta E_{\mathrm{p}} & =\frac{59}{z} \mathrm{mV}, \\
\frac{i_{\mathrm{p}}^{\mathrm{a}}}{i_{\mathrm{p}}^{\mathrm{c}}} & =1 .
\end{aligned}
$$

Table 1 compiles the calculated number of exchanged electrons $z$ of the redox process. Because of overlapping peaks it was sometimes difficult to identify the correct peak potentials. Electric charge was determined by numerical integration of the anodic branch of the cyclic voltammogram (see Figure 7). The charge needed for the $\mathrm{Ru}(\mathrm{III})$ $\rightarrow \mathrm{Ru}(\mathrm{IV})$ transition was $2014 \mu \mathrm{C} / \mathrm{cm}^{2}(0.5-1.0 \mathrm{~V}$, geometric electrode area $1 \mathrm{~cm}^{2}$, roughly $0.24 \mathrm{C}$ per real $\mathrm{cm}^{2}$ ) at $100 \mathrm{mV} / \mathrm{s}$.

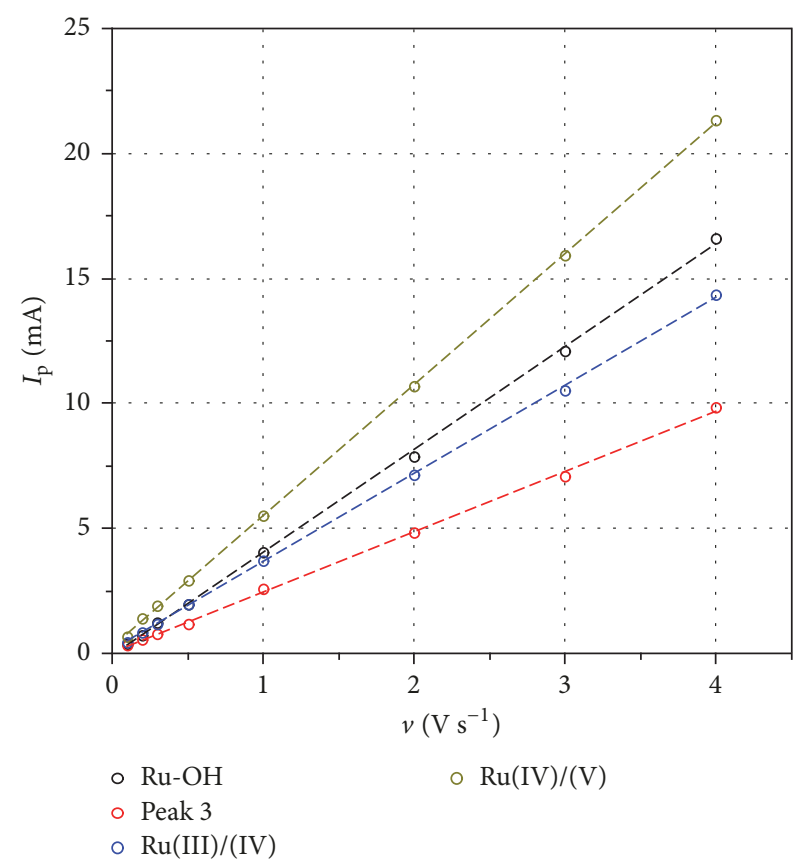

FIGURE 8: Changes of peak current with the applied scan rate of a $\mathrm{RuO}_{2} / \mathrm{Ti}$ electrode in 1-molar $\mathrm{H}_{2} \mathrm{SO}_{4}\left(25^{\circ} \mathrm{C}\right)$. Fit quality: $\mathrm{Ru}-\mathrm{OH}$ $\left(R^{2}=0.9994\right) ;$ Peak $3\left(R^{2}=0.9992\right) ; \mathrm{Ru}(\mathrm{III}) /(\mathrm{IV})\left(R^{2}=0.9996\right) ;$ $\mathrm{Ru}(\mathrm{IV}) /(\mathrm{V})\left(R^{2}=0.9999\right)$.

This value is confirmed by Doblhofer et al. who assumed $1750 \mu \mathrm{C} / \mathrm{cm}^{2}$ for one-electron change of the surface atoms [3].

Peak 1 associated with the hydrogen oxidation seems to be a reaction with poorly reversible electron passage, according to the peak current ratio between 0.76 and 0.81 .

The potential of Peak $\underline{2}$ could not be evaluated correctly because of the overlap with Peak 1 . The calculated charge between $0.055 \mathrm{~V}$ and $0.4 \mathrm{~V}$ results in a possible reaction that requires one electron. Doblhofer et al. suggested the redox reaction $\mathrm{Ru}(\mathrm{II}) \rightarrow \mathrm{Ru}(\mathrm{III})$ for this step.

A reversible electron transfer can be postulated for Peaks $\underline{4}, \underline{5}$, and $\underline{6}$. The generation of $\mathrm{Ru}(\mathrm{IV})$ from $\mathrm{Ru}(\mathrm{III})$ according to (9) needs one electron per $\mathrm{Ru}$ atom. This is approximately confirmed by both the peak potential difference and the calculated charge.

The further oxidation to $\mathrm{Ru}(\mathrm{V})$ at Peak 5 , related to (10), involves a one-electron transfer. The higher the potential is, the more the electrons are consumed by the oxygen evolution and oxidation of the electrode surface. Therefore, the electrons calculated vary with the two methods. Equation (11) suggests three electrons for the $\mathrm{Ru}(\mathrm{V}) \rightarrow \mathrm{Ru}(\mathrm{VIII})$ oxidation. This is confirmed by the peak potential method, but the calculated electrons from the charge propose a oneelectron transfer reaction $\mathrm{Ru}(\mathrm{VII}) \rightarrow \mathrm{Ru}(\mathrm{VIII})[24,25]$.

$$
\mathrm{RuO}_{4}{ }^{-} \rightleftharpoons \mathrm{RuO}_{4}+\mathrm{e}^{-}
$$

No matter what reaction takes part, the peak current ratios of Peaks $\underline{6}$ and $\underline{8}$ indicate a reversible electron transfer. Figure 8 shows the peak currents plotted against scan rates. 


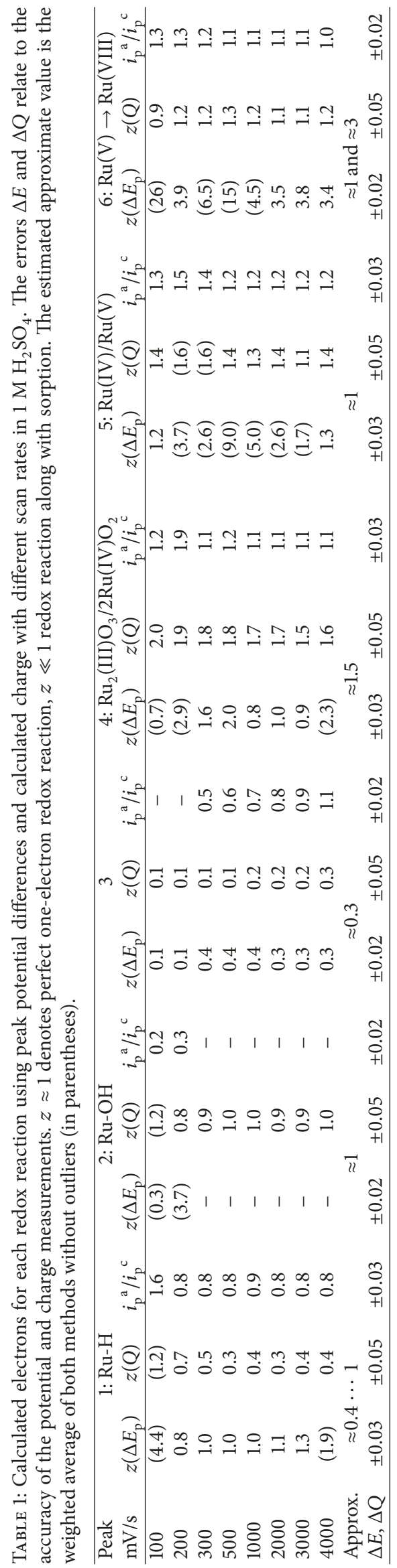


TABLE 2: Apparent diffusion coefficients at given scan rates of a $\mathrm{RuO}_{2} /$ Ti electrode assuming one-electron transfer $(z=1)$ and a real electrode surface of $120 \mathrm{~cm}^{2}$.

\begin{tabular}{lcccc}
\hline$v(\mathrm{~V} / \mathrm{s})$ & $4: \mathrm{Ru}(\mathrm{III}) /(\mathrm{IV})$ & $3: \mathrm{Ru}(\mathrm{III}) /(\mathrm{IV})$ & $5: \mathrm{Ru}(\mathrm{IV}) /(\mathrm{V})$ & $\begin{array}{c}\mathrm{D}\left(\mathrm{cm}^{2} / \mathrm{s}\right) \\
\mathrm{D}\left(\mathrm{cm}^{2} / \mathrm{s}\right)\end{array}$ \\
Solution & $\begin{array}{c}\mathrm{Ru}(\mathrm{V}) /(\mathrm{VIII}) \\
D\left(\mathrm{~cm}^{2} / \mathrm{s}\right)\end{array}$ & $1 \mathrm{M} \mathrm{H}_{2} \mathrm{SO}_{4}$ & $1.1 \cdot 10^{-14}$ \\
\hline 0.1 & $1 \mathrm{M} \mathrm{H}_{2} \mathrm{SO}_{4}$ & $1 \mathrm{M} \mathrm{NaOH}$ & $4.7 \cdot 10^{-15}$ & $2.3 \cdot 10^{-14}$ \\
0.2 & $1.9 \cdot 10^{-15}$ & $2.7 \cdot 10^{-15}$ & $9.2 \cdot 10^{-15}$ & $3.0 \cdot 10^{-14}$ \\
0.3 & $3.4 \cdot 10^{-15}$ & $5.5 \cdot 10^{-15}$ & $1.2 \cdot 10^{-14}$ & $8.7 \cdot 10^{-14}$ \\
1.0 & $4.5 \cdot 10^{-15}$ & $8.9 \cdot 10^{-15}$ & $2.9 \cdot 10^{-14}$ & $2.2 \cdot 10^{-13}$ \\
4.0 & $1.3 \cdot 10^{-14}$ & $3.5 \cdot 10^{-14}$ & $1.1 \cdot 10^{-13}$ & \\
\hline
\end{tabular}

3.3.2. Peak Currents. At first glance, all peak currents seem to change linearly with scan rate (proportionality $I_{\mathrm{p}} \sim \nu$, Figure 8). Particularly, the fast redox reactions (Peaks 2, 4, 5, and $\underline{6}$ ) involve adsorbates which cause a more or less constant interface capacitance $\left(I_{\mathrm{p}}=C v\right)$. On the contrary, the hydrogen adsorption reaction in Peak $\underline{1}$ follows $I_{\mathrm{p}} \sim v^{1 / 2}$, which indicates an electrode reaction controlled by diffusion. As well, oxygen diffusion plays a role in the redox reaction $\mathrm{Ru}(\mathrm{V}) \rightarrow \mathrm{Ru}(\mathrm{VIII})$.

3.3.3. Apparent Diffusion Coefficients. For a reversible reaction, which should be the case for Peaks $\underline{4}, \underline{5}$, and $\underline{6}$, the concentration of the active species is related to the peak current. According to the theory of cyclic voltammetry, the diffusion coefficient can be estimated by the help of RandlesSevčik equation at $25^{\circ} \mathrm{C}[30]$ :

$$
i_{\mathrm{p}}=2,686 \cdot 10^{5} z^{3 / 2} A c^{0} D^{1 / 2} v^{1 / 2}
$$

wherein $i_{\mathrm{p}}$ is peak current (in $A$ ), $A$ is electrode cross section (in $\mathrm{cm}^{2}$ ), $D$ is diffusion coefficient $\left(\mathrm{cm}^{2} \mathrm{~s}^{-1}=10^{-4} \mathrm{~m}^{2} / \mathrm{s}\right), c^{0}$ is bulk concentration of the solution $\left(\mathrm{mol} \mathrm{cm}^{-3}=1000 \mathrm{~mol} / \mathrm{L}\right)$, and $v$ is scan rate $(\mathrm{V} / \mathrm{s})$.

The apparent diffusion coefficients, compiled in Table 2 and Figure 10, differ from values calculated by the help of molar ion conductivities in infinitely diluted aqueous solution according to the Nernst-Einstein equation, $D=$ $\lambda \mathrm{RT} / F^{2}$ at $25^{\circ} \mathrm{C}$.

For the proton, $\lambda\left(\mathrm{H}^{+}\right)=0.03469 \mathrm{~S} \mathrm{~m}^{2} / \mathrm{mol}$ corresponds to $D\left(\mathrm{H}^{+}\right)=9.3 \cdot 10^{-5} \mathrm{~cm}^{2} / \mathrm{s}$. For the hydroxide ion, $\lambda\left(\mathrm{OH}^{-}\right)=$ $0.01992 \mathrm{~S} \mathrm{~m}^{2} / \mathrm{mol}$ corresponds to $D\left(\mathrm{OH}^{-}\right)=5.3 \cdot 10^{-5} \mathrm{~cm}^{2} / \mathrm{s}$.

The apparent diffusion coefficient per electrode cross section $\left(1 \mathrm{~cm}^{2}\right)$ rises at high scan rates, that is, $1.9 \cdot 10^{-10} \mathrm{~cm}^{2} / \mathrm{s}$ (at $1 \mathrm{~V} / \mathrm{s}$; and $7.1 \cdot 10^{-10} \mathrm{~cm}^{2} / \mathrm{s}(4 \mathrm{~V} / \mathrm{s}$ ) for the $\mathrm{Ru}(\mathrm{III}) / \mathrm{Ru}(\mathrm{IV})$ redox couple. With respect to the electrochemically active surface area of $120 \mathrm{~cm}^{2}$, the diffusion coefficient reads 1.3 . $10^{-14} \mathrm{~cm}^{2} / \mathrm{s}$ at $1 \mathrm{~V} / \mathrm{s}$ and $5.0 \cdot 10^{-14} \mathrm{~cm}^{2} / \mathrm{s}$ at $4 \mathrm{~V} / \mathrm{s}$ (Table 2 ). At low scan rates, the mentioned redox reactions are obviously diffusion controlled in the porous electrode, whereas at fast scan rates the reaction proceeds at the electrode surface and cannot penetrate the pores. It is interesting to note that the calculated electrons for the transition $\mathrm{Ru}(\mathrm{III}) / \mathrm{Ru}(\mathrm{IV})$ drop from $z=1$ (per Ru atom) at low scan rates to $z=0.8$ at fast scan rates. The reverse reaction $\mathrm{Ru}(\mathrm{IV}) / \mathrm{Ru}(\mathrm{III})$ yields about
$1600 \mu \mathrm{C} / \mathrm{cm}^{2}$, which results in $0.8 \pm 0.03$ electrons for nearly all scan rates. This again gives a hint at that the electrode reactions take place at the electrode surface at fast scan rates, whereas the total active electrode area can effectively be used at low scan rates only. Fast diffusion process might be attributed to the proton at the surface of the electrode, which is directly coupled with the electronic conductivity: $\mathrm{H}_{2} \rightarrow$ $2 \mathrm{H}^{+}+2 \mathrm{e}^{-}$. Zheng et al. proved this proton insertion into ruthenium oxide films prepared by pulsed laser deposition [31].

3.3.4. Oxygen and Hydrogen Evolution. Peak 7 belongs to the oxygen evolution reaction. The $\mathrm{pH}$-dependent $\mathrm{OER}$ is usually characterized by the Tafel slopes of the current-voltage characteristics [32]. The mechanism comprises the following: (i) the discharge of water molecules (acid) or $\mathrm{OH}^{-}$(alkaline) by oxidation at the surface-active sites; (ii) the intermediate $\mathrm{OH}^{*}$ being converted to $\mathrm{OH}$, (iii) the surface complex $\mathrm{M}(\mathrm{OH})_{2}$ being oxidized; and (iv) oxygen being released by the decomposition of two $\mathrm{M}(\mathrm{OH}) \mathrm{O}$ complexes [12].

In acidic solutions, the Tafel slope amounts to $30 \mathrm{mV} / \mathrm{dec}$ $\left(1 \mathrm{M} \mathrm{H}_{2} \mathrm{SO}_{4}\right.$ at $30^{\circ} \mathrm{C} \mathrm{[33]),} 42 \mathrm{mV} / \mathrm{dec}\left(1 \mathrm{M} \mathrm{H}_{2} \mathrm{SO}_{4}\right.$ at $\left.20^{\circ} \mathrm{C}\right)$ [34], and $30-50 \mathrm{mV} / \mathrm{dec}$ in $0.5 \mathrm{M} \mathrm{H}_{2} \mathrm{SO}_{4}$ at room temperature [35]. The Tafel slope depends on the acid concentration. The quasistationary voltammogram yields $52 \mathrm{mV} / \mathrm{dec}$ in $1 \mathrm{M}$ $\mathrm{H}_{2} \mathrm{SO}_{4}\left(25^{\circ} \mathrm{C}, \mathrm{pH} 0.08\right)$ above $1.52 \mathrm{~V}$ RHE; see Figure 11. The slope is $69.3 \pm 0.2 \mathrm{mV} / \mathrm{dec}(>1.5 \mathrm{~V})$ in $0.1 \mathrm{M} \mathrm{H}_{2} \mathrm{SO}_{4}(\mathrm{pH}$ $1.0)$ and $35.8 \pm 0.1 \mathrm{mV} / \mathrm{dec}(>1.48 \mathrm{~V})$ in $0.01 \mathrm{M} \mathrm{H}_{2} \mathrm{SO}_{4}(\mathrm{pH}$ 1.71) and below this potential $191.3 \pm 1.3 \mathrm{mV} / \mathrm{dec}$. Peak 14 is attributed to the hydrogen evolution reaction (HER). Our results indicate two different slopes: $-72.8 \pm 0.7 \mathrm{mV} / \mathrm{dec}$ at low current densities and $-42.3 \pm 0.1 \mathrm{mV} / \mathrm{dec}$ at high current densities (Figure 12). In 0.1-molar $\mathrm{H}_{2} \mathrm{SO}_{4}$, the slope was -89.2 $\pm 0.2 \mathrm{mV} / \mathrm{dec}$ at high current densities. In the literature, $-60 \mathrm{mV} / \mathrm{dec}$ and $-40 \mathrm{mV} / \mathrm{dec}$ were reported for low and high current densities respectively $[12,36]$. The generally accepted mechanism of the hydrogen electrode is of the VolmerHeyrovsky type:

$$
\begin{gathered}
{[\mathrm{Ru}] \mathrm{OH}+\mathrm{H}^{+}+\mathrm{e}^{-} \rightleftharpoons[\mathrm{Ru}] \mathrm{OH}_{2}} \\
{[\mathrm{Ru}] \mathrm{OH}_{2}+\mathrm{H}^{+}+\mathrm{e}^{-} \rightleftharpoons[\mathrm{Ru}] \mathrm{OH}+\mathrm{H}_{2}}
\end{gathered}
$$

3.4. Electrochemistry in Alkaline Solution. The reactions of ruthenium oxide electrodes in alkaline solutions were studied by Burke and coworkers in $1980[37,38]$. In 1-molar $\mathrm{NaOH}$ the 
OCP of $\mathrm{RuO}_{2}$ is $0.91 \mathrm{~V}$. We found 13 peaks of interest by using fast scan cyclic voltammetry (Figure 13).

The first two peaks mean 1 (at $52 \pm 13 \mathrm{mV}$ ) the hydrogen adsorption on coordinatively unsaturated Ru sites and 2 (283 $\pm 82 \mathrm{mV}$ ) the hydrogen adsorption at $\mathrm{Ru}-\mathrm{O}$, possibly $\mathrm{Ru}$ (II) exists. The corresponding reduction peaks are 11 at $420 \pm$ $67 \mathrm{mV}$ and $\underline{12}$ at $\approx 87 \pm 36 \mathrm{mV}$, respectively. At $639 \pm 30 \mathrm{mV}$, the transition of $\mathrm{Ru}(\mathrm{III}) \rightarrow \mathrm{Ru}(\mathrm{IV})$ takes place (peak $\underline{3}$ ) [24, 37, 38].

Peak $\underline{4}$ at approximately $1136 \pm 19 \mathrm{mV}$ reflects the $\mathrm{Ru}(\mathrm{IV})$ $\rightarrow \mathrm{Ru}(\mathrm{VI})$ transition. $\mathrm{Ru}(\mathrm{V})$ is not likely to appear in alkaline solutions although it might be an intermediate during the formation of $\mathrm{Ru}(\mathrm{VI}) . \mathrm{Ru}(\mathrm{VI})$ is known as ruthenate $\left(\mathrm{RuO}_{4}{ }^{2-}\right)$ in alkaline solutions $[24,27,29]$.

$$
\text { Peak 4: } \mathrm{RuO}_{4}{ }^{2-}+4 \mathrm{H}^{+}+2 \mathrm{e}^{-} \rightleftharpoons \mathrm{RuO}_{2}+2 \mathrm{H}_{2} \mathrm{O}
$$

Peak $\underline{4}$ corresponds to the reduction peak 9 at $1060 \pm 21 \mathrm{mV}$. This was confirmed by examinations using benzaldehyde and benzyl alcohol. $\mathrm{Ru}(\mathrm{VI})$ is able to oxidize benzaldehyde but not benzyl alcohol. Ru(VII) oxidizes both [24]. At about 1392 $\pm 14 \mathrm{mV}$, the striking peak $\underline{5}$ arises, and the reduction peak $\underline{8}$ at approximately $1368 \pm 5 \mathrm{mV}$. This highly reversible redox reaction reflects $\mathrm{Ru}(\mathrm{VI}) \rightarrow \mathrm{Ru}(\mathrm{VII})$.

$$
\text { Peak } \underline{5}: \mathrm{RuO}_{4}{ }^{-}+\mathrm{e}^{-} \rightleftharpoons \mathrm{RuO}_{4}{ }^{2-}
$$

Peak $\underline{5}$ appears only in strongly alkaline solutions. Burke et al. mention a potential range within $1.35-1.45 \mathrm{~V}$. This peak does not depend on $\mathrm{pH}$, but the hydroxide concentration of the solution plays a role $[24,37,38]$. The existence of perruthenate $\left(\mathrm{RuO}_{4}{ }^{-}\right)$was proved by in situ IR spectroscopy [29].

A further increase in potential leads to the oxygen evolution reaction, peak $\underline{6}$ at about $1462 \pm 34 \mathrm{mV}$. During the OER, further transition to $\mathrm{Ru}(\mathrm{VIII})$ might take place. However, $\mathrm{Ru}(\mathrm{VIII})$ is not stable in alkaline solutions [27, 29].

$$
\text { Peak ㅁ: } \mathrm{HRuO}_{5}{ }^{-}+\mathrm{H}^{+}+\mathrm{e}^{-} \rightleftharpoons \mathrm{RuO}_{4}{ }^{-}+\mathrm{H}_{2} \mathrm{O}
$$

3.4.1. Electrochemical Valency. Based on the $\mathrm{Ru}(\mathrm{III}) / \mathrm{Ru}(\mathrm{IV})$ redox couple, which requires an electric charge of approximately $2000 \mu \mathrm{C} / \mathrm{cm}^{2}$ for $z=1$ transferred electron (per Ru atom), the values in Table 3 were calculated. It is interesting to note that the calculated electrons for Peak 1 in alkaline solution differ from those in acidic solutions. There is evidence for a one-electron transfer, but the peak current ratio suggests a highly irreversible electron transfer. We conclude that Peak 1 is the hydrogen adsorption reaction on the coordinatively unsaturated $\mathrm{Ru}$ atom. The calculated electrons at Peak 2 are most surprising in the range between 1.1 and 2.8. This might be a hint at the formation $\mathrm{Ru}(\mathrm{II})$ in alkaline solutions; possibly a surface species " $\mathrm{Ru}(\mathrm{OH})_{2}$ " is able to directly bind hydroxyl ions. The peak current ratios give evidence for a reversible electron transfer, especially at fast scan rates.

The conversion of $\mathrm{Ru}(\mathrm{III})$ to $\mathrm{Ru}(\mathrm{IV})$ is known to be a highly reversible reaction. The difference of the peak potential indicates a one-electron transfer reaction as has been assumed by many authors [3]. The charge calculations give hints that $z \approx 1.5$ electrons (or protons or rather hydroxide ions) are involved per Ru atom. Burke and Healy [24] suggested therefore the following reaction:

$$
\mathrm{RuO}_{2}+2,5 \mathrm{OH}^{-} \rightleftharpoons \mathrm{RuO}_{2}(\mathrm{OH})_{2,5}{ }^{0,5-}+2 \mathrm{e}^{-}
$$

Regardless of whether $2 \mathrm{mC} / \mathrm{cm}^{2}$ is consumed by one, 1.5 , or two electrons, the peak current ratio shows a high reversibility. Closer examination of the $\mathrm{Ru}(\mathrm{IV}) / \mathrm{Ru}(\mathrm{III})$ peak 10 shows a two-electron transfer reaction at low scan rates, and a one-electron transfer at high scan rates. It is striking that the calculated electrons give exactly $z=2(<300 \mathrm{mV} / \mathrm{s})$, $z=1.5$ at $300 \mathrm{mV} / \mathrm{s}$, and $z=1(>300 \mathrm{mV} / \mathrm{s})$. Obviously, a slow and a fast step is involved in the $\mathrm{Ru}(\mathrm{III}) / \mathrm{Ru}(\mathrm{IV})$ transition.

As expected peak $\underline{5}$, the $\mathrm{Ru}(\mathrm{IV}) \rightarrow \mathrm{Ru}(\mathrm{VI})$ reaction, involves 2 electrons and shows high reversibility.

Peak $\underline{6}$ is the transition of $\mathrm{Ru}(\mathrm{VI}) \rightarrow \mathrm{Ru}(\mathrm{VII})$. Higher oxides are more stable in alkaline solution than in acids, and this peak only appears at this alkaline $\mathrm{pH}$ [39].

$\mathrm{Chu}$ et al. [4] demonstrated the presence of two types of water monolayers having different densities at the $\mathrm{RuO}_{2}(110)$-water interface in $0.1 \mathrm{M} \mathrm{NaOH}$. At potentials close to the OER, external water molecules and surface hydroxide form a bilayer with $\mathrm{O}-\mathrm{H}-\mathrm{O}$ bond distances similar to that of ice (Figure 14).

The oxygen evolution $\underline{6}$ is followed by the reduction peak 7. This shoulder in the voltammogram is caused by the $\mathrm{Ru}(\mathrm{VIII}) \rightarrow \mathrm{Ru}(\mathrm{VII})$ transition. Thermodynamic calculations for (19) result in the potential $E^{0}=1.678 \mathrm{~V}(11.53<\mathrm{pH}<$ 14.00 ), so that this transition most likely takes place during the OER.

3.4.2. Peak Currents. With respect to the correlation between peak current and scan rate (Figure 15), peak 1 could not be evaluated correctly at fast scan rates due to overlap with peak 2. In alkaline solution, the so-called hydrogen adsorption might result from the high hydroxide concentration rather than from hydrogen or hydronium ions. Peak 2 shows $I_{\mathrm{p}} \sim$ $\nu^{1 / 2}$ at fast scan rates $(>500 \mathrm{mV} / \mathrm{s})$ and $I_{\mathrm{p}} \sim \nu$ at low speed.

The similar properties of Peak $\underline{2}$ and Peak $\underline{3}$ might indicate a more or less stable species in alkaline solutions, that is, $\mathrm{Ru}(\mathrm{II})$ or a mixed species of $\mathrm{Ru}(\mathrm{I})$ and $\mathrm{Ru}(\mathrm{III})$. We propose these species based on the calculated number of transferred electrons (Table 3). $\mathrm{Ru}(\mathrm{II})$ is known in complexes, especially such containing chloride ligands. Mercer and Buckley [40] characterized hexaaquaruthenium(II) $\left[\mathrm{Ru}\left(\mathrm{H}_{2} \mathrm{O}\right)_{6}\right]^{2+}$ in aqueous solution by electrolytic reduction of $\mathrm{Ru}(\mathrm{III})$. The oxidation state was verified by coulometry and titration with triiodide, which might be a coincidence, the potential of peak 2 in acidic solution $(143 \pm 9 \mathrm{mV})$ is half that in alkaline solution $(283 \pm 82 \mathrm{mV})$, where $\mathrm{Ru}$ (II) forms stable hydroxospecies in contrast to a cluster ion in acids. Peak $\underline{4}$ and Peak $\underline{5}$ obey roughly $I_{\mathrm{p}} \sim \nu$. Peak $\underline{5}$ involves the adsorption of external water molecules.

3.4.3. Apparent Diffusion Coefficient. According to RandlesSevčik equation at $25^{\circ} \mathrm{C}$, the apparent diffusion coefficients are compiled in Figure 16. The redox couples $\mathrm{Ru}(\mathrm{II}) / \mathrm{Ru}(\mathrm{III})$ and $\mathrm{Ru}(\mathrm{VI}) / \mathrm{Ru}(\mathrm{VII})$ behave similarly during the oxidation. 


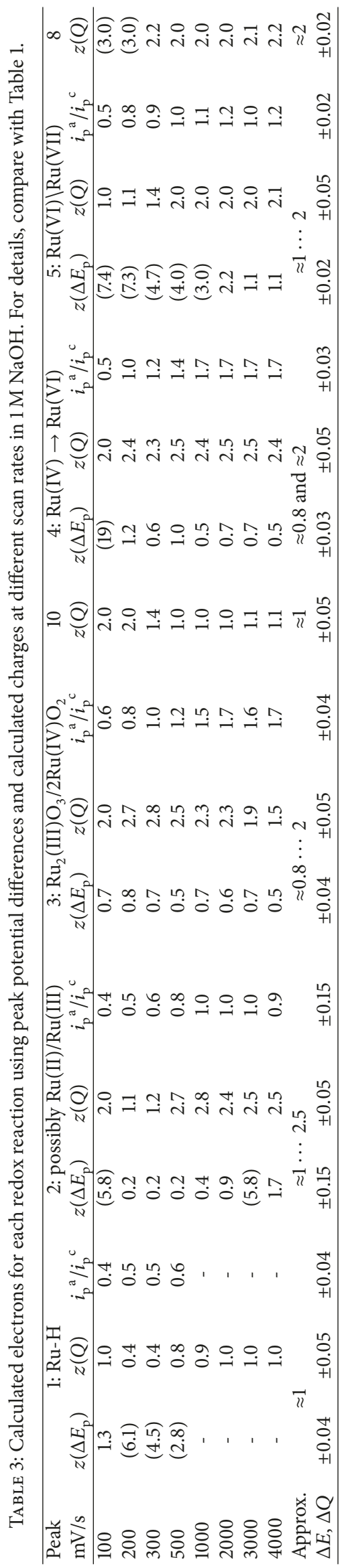




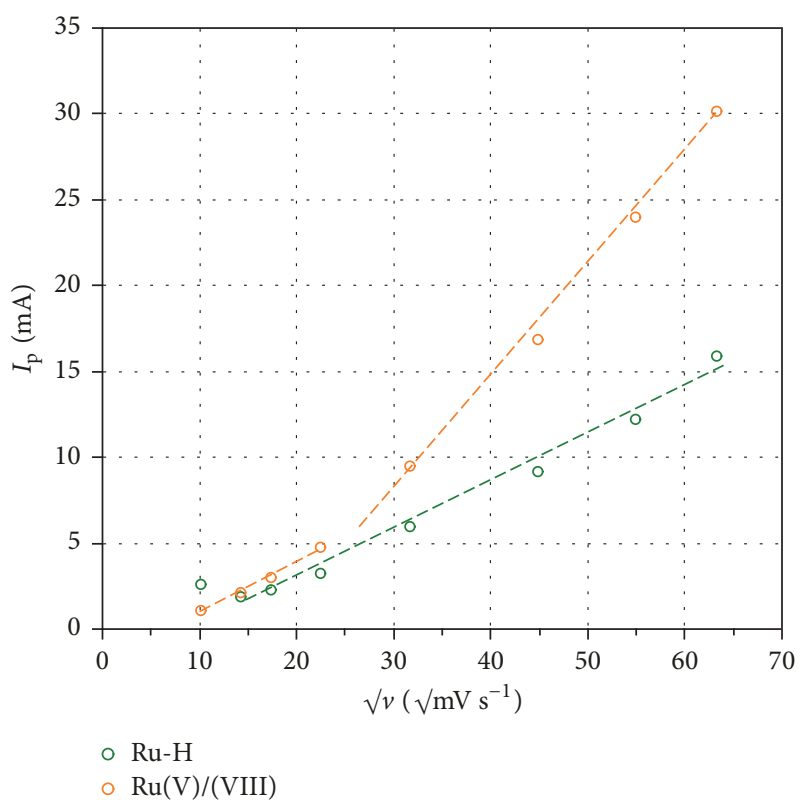

FIGURE 9: Changes of peak current against the square root of scan rate in order to identify diffusion and adsorption controlled electrochemical processes. Fit quality: $\mathrm{Ru}-\mathrm{H}\left(R^{2}=0.989 ; 0.2-4 \mathrm{~V} / \mathrm{s}\right)$; $\mathrm{Ru}(\mathrm{V}) /(\mathrm{VIII})\left(R^{2}=0.995 ; 0.1-0.5 \mathrm{~V} / \mathrm{s} ; R^{2}=0.996 ;>1.0 \mathrm{~V} / \mathrm{s}\right)$.

The diffusion coefficients of $\mathrm{Ru}(\mathrm{III}) / \mathrm{Ru}(\mathrm{IV})$ and vice versa behave differently, so that the apparent diffusion coefficient is higher in alkaline solution than in acid solution; see Table 2. This can be explained by a stronger oxide growth in alkaline solution due to the formation of more permeable and crystalline deposits [39].

3.4.4. Oxygen and Hydrogen Evolution. The oxygen evolution reaction $[23,41-43]$ in $1 \mathrm{M} \mathrm{NaOH}$ can be divided into two regions. The Tafel slope amounts to (i) $93 \mathrm{mV} / \mathrm{dec}$ below $1.5 \mathrm{~V}$ and (ii) $42 \mathrm{mV} / \mathrm{dec}$ above $1.5 \mathrm{~V}$; see Figure 11 . Two different slopes were also observed during the hydrogen evolution reaction in $1 \mathrm{M} \mathrm{NaOH}$. In the literature, $30-60 \mathrm{mV} / \mathrm{dec}$ and $120 \mathrm{mV} / \mathrm{dec}$ can be found for steady-state measurements [12]. Two different slopes were also observed for the hydrogen evolution reaction: (i) $40-50 \mathrm{mV} / \mathrm{dec}$ at low current densities and (ii) $230-240 \mathrm{mV} / \mathrm{dec}$ at high current densities [12]. The different slopes suggest a change in the reaction regime depending on current [12].

\section{Conclusion and Outlook}

This paper gives a comprehensive overview on the redox electrochemistry and voltammetric behavior of ruthenium dioxide, which cannot be found in detail in the literature. For the first time, all the 13 voltammetric peaks were assigned to a consistent set of electrode reactions both in acid and in alkaline solution. A most illustrative mechanism for the dissociative adsorption of water that causes the redox activity of $\mathrm{RuO}_{2}$ is given in Figure 5 .

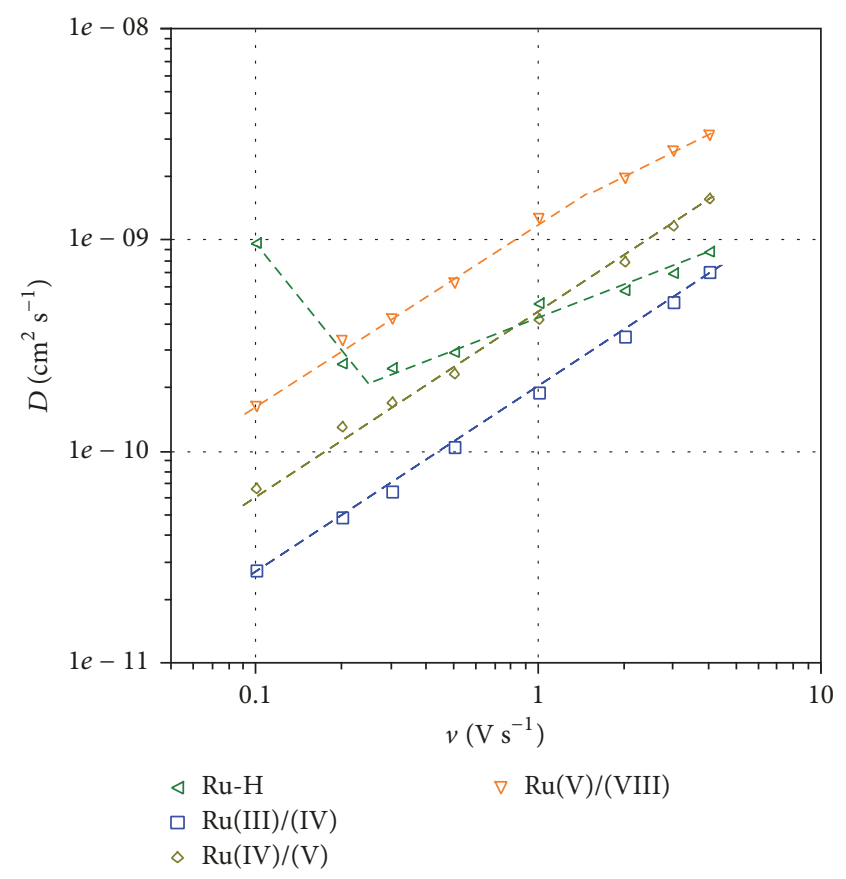

FIGURE 10: Apparent diffusion coefficients at different scan rates

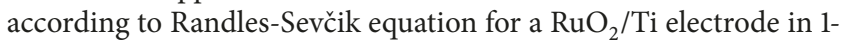
molar $\mathrm{H}_{2} \mathrm{SO}_{4}$ at $25^{\circ} \mathrm{C}$ assuming one-electron transfer $(z=1)$ and unit surface area $\left(1 \mathrm{~cm}^{2}\right)$ for reason of comparability. Fit quality: $\mathrm{Ru}-$ $\mathrm{H}\left(R^{2}=0.9511,>0.3 \mathrm{~V} / \mathrm{s}\right) ; \mathrm{Ru}(\mathrm{III}) /(\mathrm{IV})\left(R^{2}=0.9952\right) ; \mathrm{Ru}(\mathrm{IV}) /(\mathrm{V})$ $\left(R^{2}=0.9995\right) ; \mathrm{Ru}(\mathrm{V}) /(\mathrm{VIII})\left(R^{2}=0.997 ; 0.1-1 \mathrm{~V} / \mathrm{s}\right)$ and $\left(R^{2}=0.991\right.$; $>1 \mathrm{~V} / \mathrm{s})$.

(1) Under fast scan rates up to $4000 \mathrm{mV} / \mathrm{s}, 13$ peaks were identified in acidic and in alkaline solution, which reflect the high reversibility of $\mathrm{RuO}_{2}$. The underlying electrode reactions were compiled for each peak with respect to the more recent literature and our own observations. The peak current $I$ of most peaks, especially the $\mathrm{Ru}(\mathrm{III}) / \mathrm{Ru}(\mathrm{IV})$ transition, increases with rising scan rate $v$ which is due to the capacitive properties of the metal oxide surface $(I=C v)$. Diffusion controlled processes that cause a nonlinear function $I \sim v^{1 / 2}$ were observed for the hydrogen sorption.

(2) Below $0.4 \mathrm{~V}$ RHE, in the "hydrogen adsorption region," the dissociate adsorption of water takes place, whereby $\mathrm{Ru}-\mathrm{OH}$ species are formed. In the hydrogen region, $\mathrm{Ru}(\mathrm{II})$ or a mixed species $\mathrm{Ru}(\mathrm{I})-\mathrm{Ru}(\mathrm{III})$ is likely to be present, which we proved by the help of voltammetric charge. In alkaline solution, the aqua complex $\left[\mathrm{Ru}\left(\mathrm{H}_{2} \mathrm{O}\right)_{6}\right]^{2+}$ seems reasonable $(283 \pm 82 \mathrm{mV})$ according to our results, whereas in the solid material a mixed-valent hydroxospecies is likely to be.

(3) Above $0.4 \mathrm{~V}$ RHE the ruthenium surface passes through the oxidation states III $\rightarrow$ IV $\rightarrow \mathrm{V} \rightarrow$ VIII in acids and $\mathrm{III} \rightarrow \mathrm{IV} \rightarrow \mathrm{VI} \rightarrow \mathrm{VII} \rightarrow$ (VIII) in alkaline solution. We found that the electrochemical valency is different in alkaline and acidic solution; therefore, the redox processes cannot be written with general equations for any $\mathrm{pH}$ value.

(4) The $\mathrm{Ru}(\mathrm{III}) / \mathrm{Ru}(\mathrm{IV})$ couple is involved in a oneelectron electron transfer (per Ru atom). Hints at $z \approx 1.5$ suggest complex cluster species. Simplifying, we propose a 


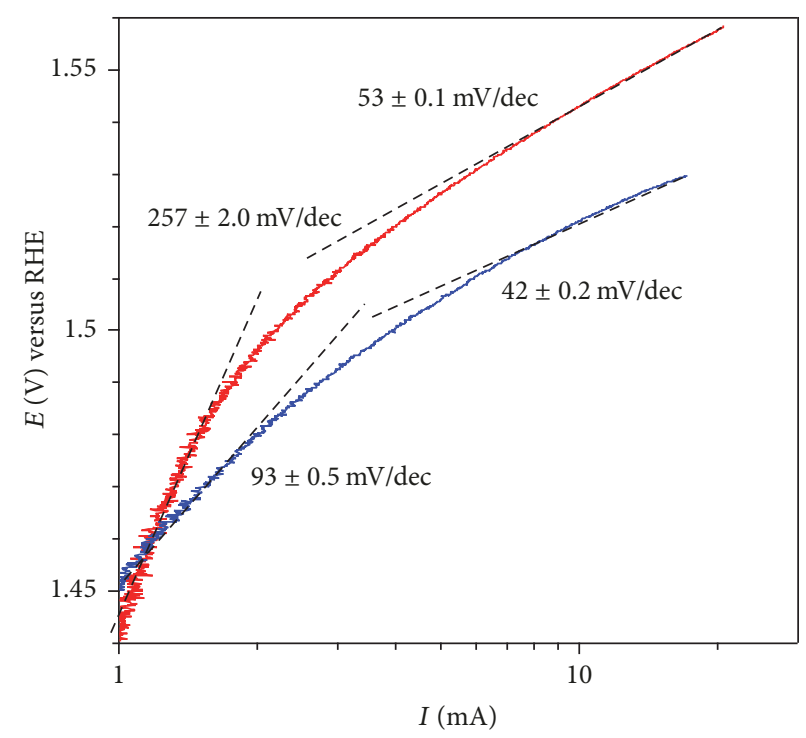

Figure 11: Oxygen evolution at a $\mathrm{Ti} / \mathrm{RuO}_{2}$ electrode in $1 \mathrm{M} \mathrm{H}_{2} \mathrm{SO}_{4}$ (red line) and $1 \mathrm{M} \mathrm{NaOH}$ (blue line) at $25^{\circ} \mathrm{C}$ derived from cyclic voltammogram (oxidation sweep at $100 \mathrm{mV} / \mathrm{s}$ ).

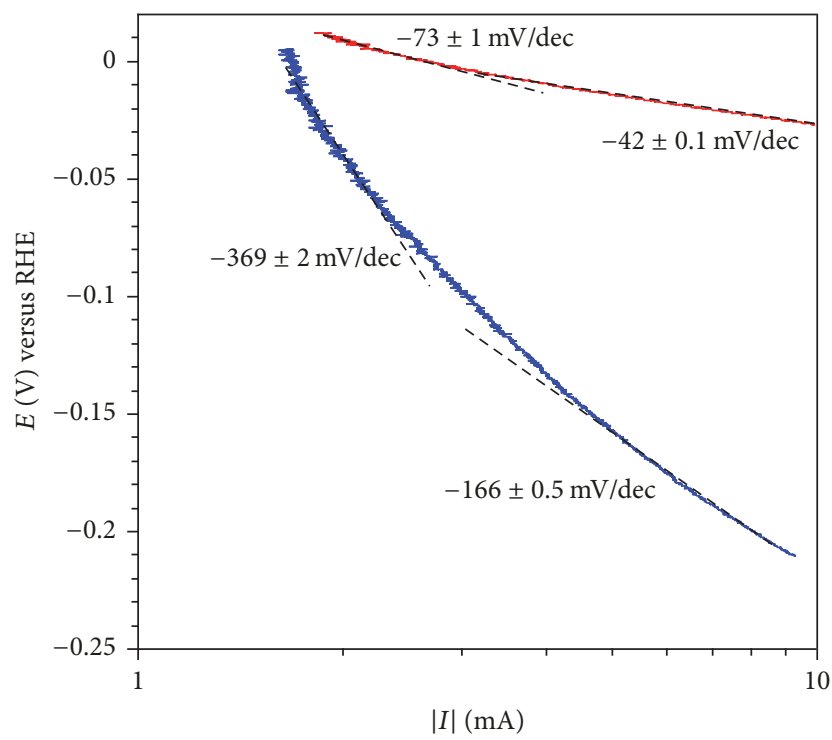

FIgURE 12: Hydrogen evolution at a Ti/ $\mathrm{RuO}_{2}$ electrode in $1 \mathrm{M} \mathrm{H}_{2} \mathrm{SO}_{4}$ (red line) and $1 \mathrm{M} \mathrm{NaOH}$ (blue line) at $25^{\circ} \mathrm{C}$ derived from cyclic voltammogram (reduction sweep at $100 \mathrm{mV} / \mathrm{s}$ ).

species $\mathrm{Ru}(\mathrm{OH})_{3} \cdot \mathrm{RuO}_{2}$ that is present at the electrode surface and explains the oxygen surplus found in the EDX analysis.

(5) The diffusion coefficients according to Randles-Sevčik equation allow distinguishing pore diffusion at low scan rates from rapid surface diffusion of adsorbates at fast scans. On the other hand, these values show that diffusion coefficients deduced by $\mathrm{CV}$ peaks must be treated with caution, especially at high scan rates. $\mathrm{RuO}_{2}$ is known for its high pseudocapacitance [13], $C=\mathrm{d} Q / \mathrm{d} E$, which results from large potential gradients across the oxide-electrolyte interface. Therefore,

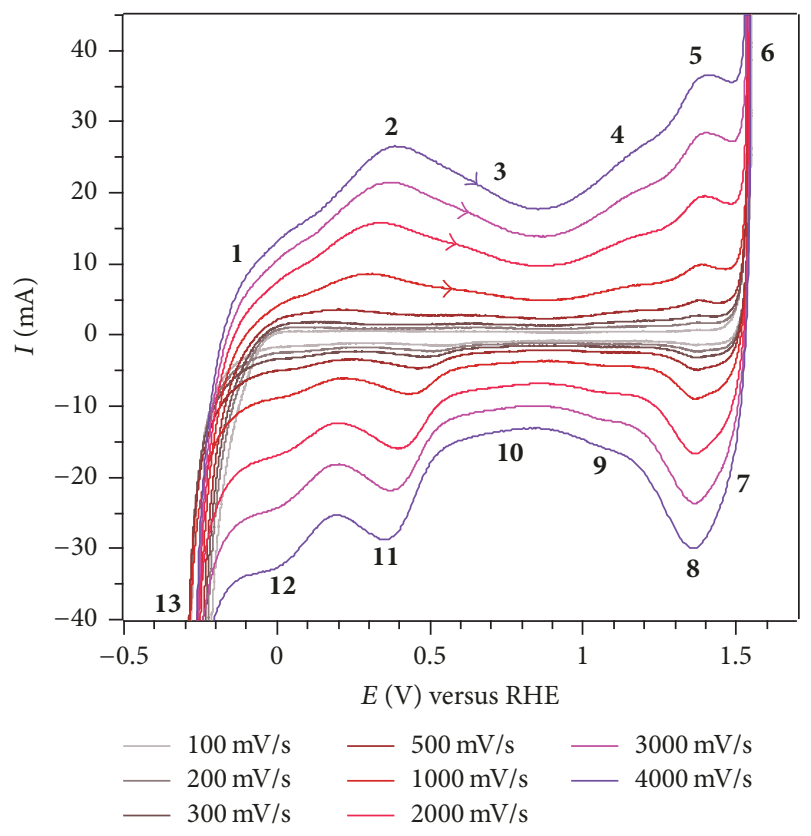

FIgure 13: Cyclic voltammograms of a $\mathrm{RuO}_{2} / \mathrm{Ti}$ electrode in $1 \mathrm{M}$ $\mathrm{NaOH}(\mathrm{pH}$ 12.93) at different scan rates. Reference: reversible hydrogen electrode. The electrolyte resistance was corrected $\left(R_{e}=\right.$ $2.8 \Omega$ ). Arrows: oxidation wave in anodic direction.

we suggest evaluating the inflexion points in Figures 9 and 15 with respect to a change of mass transport. At low scan rates, diffusion is able to penetrate into the depth of the porous material, whereas fast scan rates just allow doublelayer charging at the electrode surface. We conclude that the proton is fast enough to take part in the redox reaction $\mathrm{Ru}(\mathrm{III}) / \mathrm{Ru}(\mathrm{IV})$, even above $1000 \mathrm{mV} / \mathrm{s}$ without significant limitation by diffusion. Once adsorbed hydrogen or oxygen 

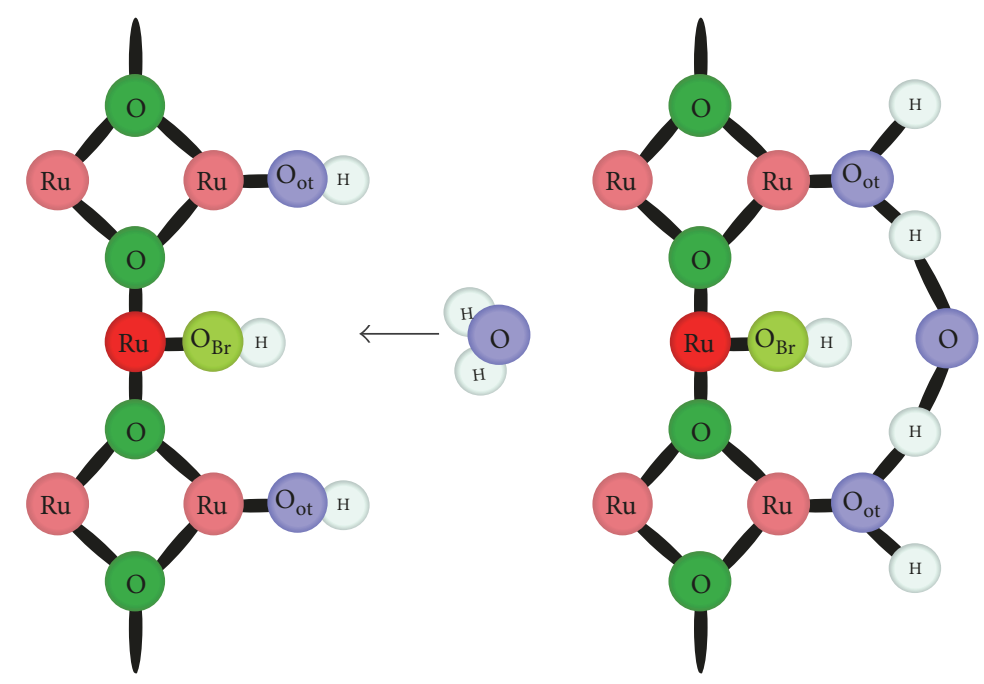

Figure 14: Formation of double layer similar to ice from external water molecule adsorption at $1.39 \mathrm{~V}$ on hydroxyl groups (modified after $[4])$.

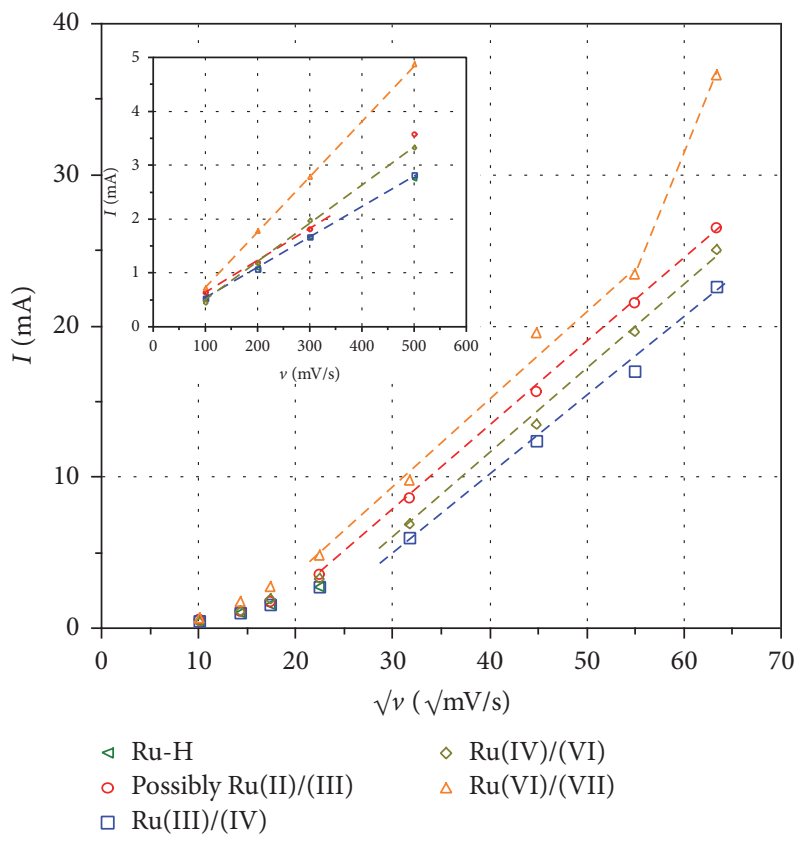

FIGURE 15: Voltammetric peak currents against the square root of scan rate: $\mathrm{RuO}_{2} / \mathrm{Ti}$ electrode in $1 \mathrm{M} \mathrm{NaOH}$; Insert: peak current versus scan rate. Fit quality for $I_{\mathrm{p}} \sim v(0.1-0.5 \mathrm{~V} / \mathrm{s}): \mathrm{Ru}-\mathrm{H}\left(R^{2}\right.$ = 0.9999); possibly $\mathrm{Ru}(\mathrm{II}) /(\mathrm{III})\left(R^{2}=0.988\right) ; \mathrm{Ru}(\mathrm{III}) /(\mathrm{IV})\left(R^{2}=\right.$ 0.9998); $\mathrm{Ru}(\mathrm{IV}) /(\mathrm{VI})\left(R^{2}=0.9991\right) ; \mathrm{Ru}(\mathrm{VI}) /(\mathrm{VII})\left(R^{2}=1\right)$; fit quality for $I_{\mathrm{p}} \sim v^{1 / 2}(>1.0 \mathrm{~V} / \mathrm{s})$ : possibly $\mathrm{Ru}(\mathrm{II}) /(\mathrm{III})\left(R^{2}=0.9996\right)$; $\mathrm{Ru}(\mathrm{III}) /(\mathrm{IV})\left(R^{2}=0.994\right) ; \mathrm{Ru}(\mathrm{IV}) /(\mathrm{VI})\left(R^{2}=0.996\right) ; \mathrm{Ru}(\mathrm{VI}) /(\mathrm{VII})$ $\left(R^{2}=0.939\right)$.

species are involved, the slope $\mathrm{d} D / \mathrm{d} v$ gets smaller, and the inflexion point lies at a far lower scan rate. Summarizing, a constant diffusion coefficient was not found even in the voltper-second range.

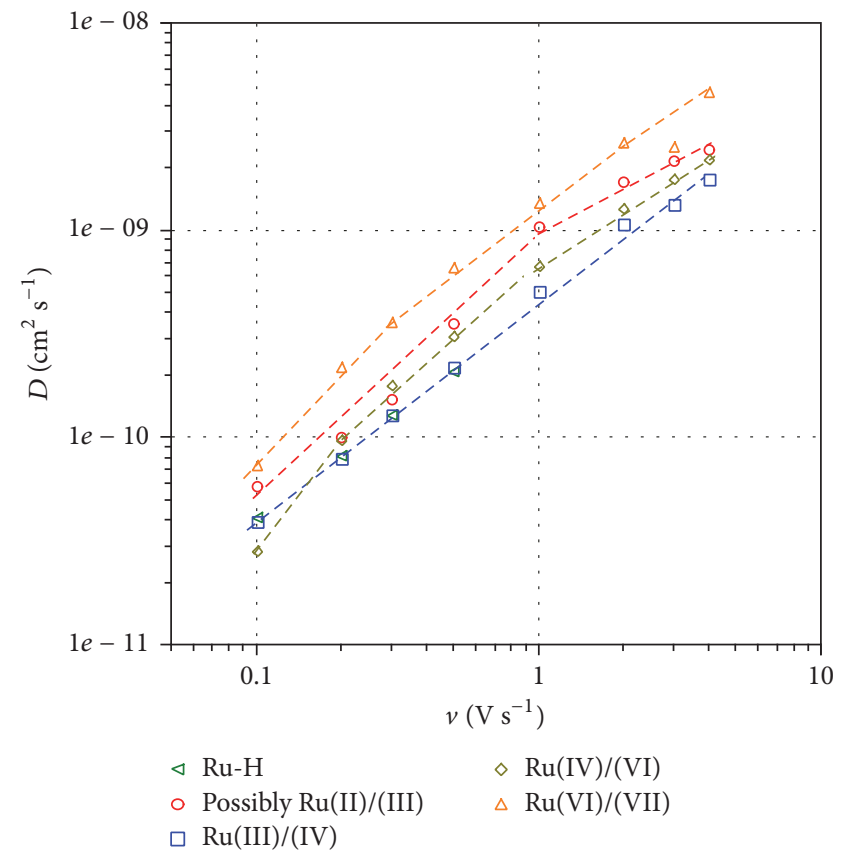

FIgURE 16: Apparent diffusion coefficients at different scan rates: $\mathrm{RuO}_{2} / \mathrm{Ti}$ electrode in $1 \mathrm{M} \mathrm{NaOH}$ at $25^{\circ} \mathrm{C}$ assuming one-electron transfer $(z=1)$ and unit surface area $\left(1 \mathrm{~cm}^{2}\right)$ for reason of comparability. Fit quality: Ru-H $\left(R^{2}=0.9996 ; 0.1-0.4 \mathrm{~V} / \mathrm{s}\right)$; possibly $\mathrm{Ru}(\mathrm{II}) /(\mathrm{III})\left(R^{2}=0.961 ; 0.1-0.5 \mathrm{~V} / \mathrm{s}\right)$ and $\left(R^{2}=0.965 ;>0.5 \mathrm{~V} / \mathrm{s}\right)$; $\mathrm{Ru}(\mathrm{III}) /(\mathrm{IV})\left(R^{2}=0.991\right) ; \mathrm{Ru}(\mathrm{IV}) /(\mathrm{VI})\left(R^{2}=0.998 ; 0.1-0.5 \mathrm{~V} / \mathrm{s}\right)$ and $\left(R^{2}=0.993 ;>1.0 \mathrm{~V} / \mathrm{s}\right) ; \mathrm{Ru}(\mathrm{VI}) /(\mathrm{VII})\left(R^{2}=0.9998 ; 0.1-0.3 \mathrm{~V} / \mathrm{s}\right)$ and $\left(R^{2}=0.932,>0.3 \mathrm{~V} / \mathrm{s}\right)$.

\section{Conflicts of Interest}

The authors declare that they have no conflicts of interest. 


\section{Acknowledgments}

This work was financially supported by the Bavarian State Ministry of the Environment and Consumer Protection.

\section{References}

[1] P. Kurzweil, "Metal oxides and ion-exchanging surfaces as $\mathrm{pH}$ sensors in liquids: state-of-the-art and outlook," Sensors, vol. 9, no. 6, pp. 4955-4985, 2009.

[2] Y. Takasu, W. Sugimoto, Y. Nishiki, and S. Nakamatsu, "Structural analyses of $\mathrm{RuO}_{2}-\mathrm{TiO}_{2} / \mathrm{Ti}$ and $\mathrm{IrO}_{2}-\mathrm{RuO}_{2}-\mathrm{TiO}_{2} / \mathrm{Ti}$ anodes used in industrial chlor-alkali membrane processes," Journal of Applied Electrochemistry, vol. 40, no. 10, pp. 1789-1795, 2010.

[3] K. Doblhofer, M. Metikos, Z. Ogumi, and H. Gerischer, "Electrochemical oxidation and reduction of the $\mathrm{RuO}_{2} / \mathrm{Ti}$ electrode surface," Berichte der Bunsen-Gesellschaft: Physical Chemistry, Chemical Physics, vol. 82, no. 10, pp. 1046-1050, 1978.

[4] Y. S. Chu, T. E. Lister, W. G. Cullen, H. You, and Z. Nagy, "Commensurate water monolayer at the $\mathrm{RuO}_{2}$ (110)/water interface," Physical Review Letters, vol. 86, no. 15, pp. 3364-3367, 2001.

[5] S. Trasatti and G. Buzzanca, "Ruthenium dioxide: A new interesting electrode material. Solid state structure and electrochemical behaviour," Journal of Electroanalytical Chemistry, vol. 29, no. 2, pp. A1-A5, 1971.

[6] D. O. Wipf, E. W. Kristensen, M. R. Deakin, and R. M. Wightman, "Fast-Scan cyclic voltammetry as a method to measure rapid, heterogenous electron-transfer kinetics," Analytical Chemistry, vol. 60, no. 4, pp. 306-310, 1988.

[7] C. E. John and S. R. Jones, Fast Scan Cyclic Voltammetry of Dopamine and Serotonin in Mouse Brain Slices, Electrochemical Methods for Neuroscience, CRC Press/Taylor and Francis, Boca Raton, FL, USA, 2007.

[8] A. E. Newkirk and D. W. McKee, "Thermal decomposition of rhodium, iridium, and ruthenium chlorides," Journal of Catalysis, vol. 11, no. 4, pp. 370-377, 1968.

[9] R. F. Savinell, R. L. Zeller, and J. A. Adams, "Electrochemically active surface area: voltammetric charge correlations for ruthenium and iridium dioxide electrodes," Journal of The Electrochemical Society, vol. 137, no. 2, pp. 489-494, 1990.

[10] T. Hepel, F. H. Pollak, and W. E. O'Grady, "Effect of crystallographic orientation of single-crystal $\mathrm{ru}_{2}$ electrodes on the hydrogen adsorption reactions," Journal of The Electrochemical Society, vol. 131, no. 9, pp. 2094-2100, 1984.

[11] H. J. Zhang, B. Lu, H. Y. Li, S. N. Bao, and P. He, "Scanning tunneling microscopy and ultraviolet photoemission spectroscopy studies of oxygen adsorption on Ru(1010)," Surface Science, vol. 556, no. 1, pp. 63-68, 2004.

[12] H. Over, "Surface chemistry of ruthenium dioxide in heterogeneous catalysis and electrocatalysis: From fundamental to applied research," Chemical Reviews, vol. 112, no. 6, pp. 33563426, 2012.

[13] P. Kurzweil, "Precious metal oxides for electrochemical energy converters: pseudocapacitance and $\mathrm{pH}$ dependence of redox processes," Journal of Power Sources, vol. 190, no. 1, pp. 189-200, 2009.

[14] H. Over, A. P. Seitsonen, E. Lundgren, M. Schmid, and P. Varga, "Experimental and simulated STM images of stoichiometric and partially reduced $\mathrm{RuO}_{2}(110)$ surfaces including adsorbates," Surface Science, vol. 515, no. 1, pp. 143-156, 2002.
[15] H. Over and A. P. Seitsonen, "Surface chemistry: Oxidation of metal surfaces," Science, vol. 297, no. 5589, pp. 2003-2005, 2002.

[16] M. Todorova, W. X. Li, M. V. Ganduglia-Pirovano, C. Stampfl, K. Reuter, and M. Scheffler, "Role of subsurface oxygen in oxide formation at transition metal surfaces," Physical Review Letters, vol. 89, no. 9, Article ID 096103, pp. 961031-961034, 2002.

[17] D. Galizzioli, F. Tantardini, and S. Trasatti, "Ruthenium dioxide: a new electrode material. I. Behaviour in acid solutions of inert electrolytes," Journal of Applied Electrochemistry, vol. 4, no. 1, pp. 57-67, 1974.

[18] S. Hadži-Jordanov, H. Angerstein-Kozlowska, and B. E. Conway, "Surface oxidation and $\mathrm{H}$ deposition at ruthenium electrodes: Resolution of component processes in potential-sweep experiments," Journal of Electroanalytical Chemistry, vol. 60, no. 3, pp. 359-362, 1975.

[19] D. Michell, D. A. J. Rand, and R. Woods, "A study of ruthenium electrodes by cyclic voltammetry and X-ray emission spectroscopy," Journal of Electroanalytical Chemistry, vol. 89, no. 1, pp. 11-27, 1978.

[20] R. Koncki and M. Mascini, "Screen-printed ruthenium dioxide electrodes for $\mathrm{pH}$ measurements," Analytica Chimica Acta, vol. 351, no. 1-3, pp. 143-149, 1997.

[21] L. Manjakkal, K. Zaraska, K. Cvejin, J. Kulawik, and D. Szwagierczak, "Potentiometric $\mathrm{RuO} 2-\mathrm{Ta} 2 \mathrm{O} 5 \mathrm{pH}$ sensors fabricated using thick film and LTCC technologies," Talanta, vol. 147, pp. 233-240, 2016.

[22] D. Galizzioli, F. Tantardini, and S. Trasatti, "Ruthenium dioxide: a new electrode material. II. Non-stoichiometry and energetics of electrode reactions in acid solutions," Journal of Applied Electrochemistry, vol. 5, no. 3, pp. 203-214, 1975.

[23] L. D. Burke, O. J. Murphy, J. F. O’Neill, and S. Venkatesan, "The oxygen electrode. Part 8. - Oxygen evolution at ruthenium dioxide anodes," Journal of the Chemical Society, Faraday Transactions 1: Physical Chemistry in Condensed Phases, vol. 73, pp. 1659-1671, 1977.

[24] L. D. Burke and J. F. Healy, "The importance of reactive surface groups with regard to the electrocatalytic behaviour of oxide (especially $\mathrm{RuO}_{2}$ ) anodes," Journal of Electroanalytical Chemistry, vol. 124, no. 1-2, pp. 327-332, 1981.

[25] E. J. M. O'Sullivan and E. J. Calvo, "Chapter 3 reactions at metal oxide electrodes," Comprehensive Chemical Kinetics, vol. 27, pp. 247-360, 1988.

[26] R. Kötz, H. J. Lewerenz, and S. Stucki, "XPS studies of oxygen evolution on $\mathrm{Ru}$ and $\mathrm{RuO}_{2}$ Anodes," Journal of The Electrochemical Society, vol. 130, no. 4, pp. 825-829, 1983.

[27] I. Povar and O. Spinu, "Ruthenium redox equilibria: 3. Pourbaix diagrams for the systems $\mathrm{Ru}-\mathrm{H}_{2} \mathrm{O}$ and $\mathrm{Ru}-\mathrm{Cl}^{-}-\mathrm{H}_{2} \mathrm{O}$," Journal of Electrochemical Science and Engineering, vol. 6, no. 1, pp. 145153, 2016.

[28] R. Kötz, S. Stucki, D. Scherson, and D. M. Kolb, "In-situ identification of $\mathrm{RuO}_{4}$ as the corrosion product during oxygen evolution on ruthenium in acid media," Journal of Electroanalytical Chemistry, vol. 172, no. 1-2, pp. 211-219, 1984.

[29] A. Bewick, C. Gutiérrez, and G. Larramona, "In-situ IR spectroscopy study of the ruthenium electrode in acid and alkaline solutions," Journal of Electroanalytical Chemistry, vol. 332, no. 1-2, pp. 155-167, 1992.

[30] M. Barbooti, Environmental Applications of Instrumental Chemical Analysis, Apple Academic Press, 2015.

[31] J. P. Zheng, T. R. Jow, Q. X. Jia, and X. D. Wu, "Proton insertion into ruthenium oxide film prepared by pulsed laser deposition," 
Journal of The Electrochemical Society, vol. 143, no. 3, pp. 10681070, 1996.

[32] K. A. Stoerzinger, R. R. Rao, X. R. Wang, W. T. Hong, C. M. Rouleau, and Y. Shao-Horn, "The Role of Ru Redox in $\mathrm{pH}$-Dependent oxygen evolution on rutile ruthenium dioxide surfaces," Chemistry of Materials, vol. 2, no. 5, pp. 668-675, 2017.

[33] C. Iwakura, K. Hirao, and H. Tamura, "Anodic evolution of oxygen on ruthenium in acidic solutions," Electrochimica Acta, vol. 22, no. 4, pp. 329-334, 1977.

[34] E. Fabbri, A. Habereder, K. Waltar, R. Kötz, and T. J. Schmidt, "Developments and perspectives of oxide-based catalysts for the oxygen evolution reaction," Catalysis Science and Technology, vol. 4, no. 11, pp. 3800-3821, 2014.

[35] M. Vuković, "Oxygen evolution on an electrodeposited ruthenium electrode in acid solution -the effect of thermal treatment," Electrochimica Acta, vol. 34, no. 2, pp. 287-291, 1989.

[36] E. R. Kötz and S. Stucki, "Ruthenium dioxide as a hydrogenevolving cathode," Journal of Applied Electrochemistry, vol. 17, no. 6, pp. 1190-1197, 1987.

[37] L. D. Burke and O. J. Murphy, "The electrochemical behaviour of $\mathrm{RuO}_{2}$-based mixed-oxide anodes in base," Journal of Electroanalytical Chemistry, vol. 109, no. 1-3, pp. 199-212, 1980.

[38] L. D. Burke and D. P. Whelan, "The behaviour of ruthenium anodes in base," Journal of Electroanalytical Chemistry, vol. 103, no. 2, pp. 179-187, 1979.

[39] L. D. Burke, J. K. Mulcahy, and S. Venkatesan, "An investigation of anodic film formation on electrodeposited ruthenium by potential sweep techniques," Journal of Electroanalytical Chemistry, vol. 81, no. 2, pp. 339-346, 1977.

[40] E. E. Mercer and R. R. Buckley, "Hexaaquoruthenium(II)," Inorganic Chemistry, vol. 4, no. 12, pp. 1692-1695, 1965.

[41] T. Reier, M. Oezaslan, and P. Strasser, "Electrocatalytic oxygen evolution reaction (OER) on $\mathrm{Ru}$, Ir, and pt catalysts: a comparative study of nanoparticles and bulk materials," ACS Catalysis, vol. 2, no. 8, pp. 1765-1772, 2012.

[42] M. H. Miles, E. A. Klaus, B. P. Gunn, J. R. Locker, W. E. Serafin, and S. Srinivasan, "The oxygen evolution reaction on platinum, iridium, ruthenium and their alloys at $80^{\circ} \mathrm{C}$ in acid solutions," Electrochimica Acta, vol. 23, no. 6, pp. 521-526, 1978.

[43] Y. Lee, J. Suntivich, K. J. May, E. E. Perry, and Y. Shao-Horn, "Synthesis and activities of rutile $\mathrm{IrO}_{2}$ and $\mathrm{RuO}_{2}$ nanoparticles for oxygen evolution in acid and alkaline solutions," The Journal of Physical Chemistry Letters, vol. 3, no. 3, pp. 399-404, 2012. 

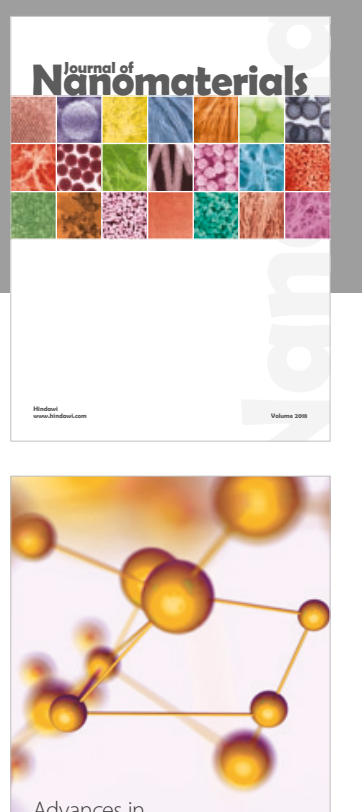

Physical Chemistry
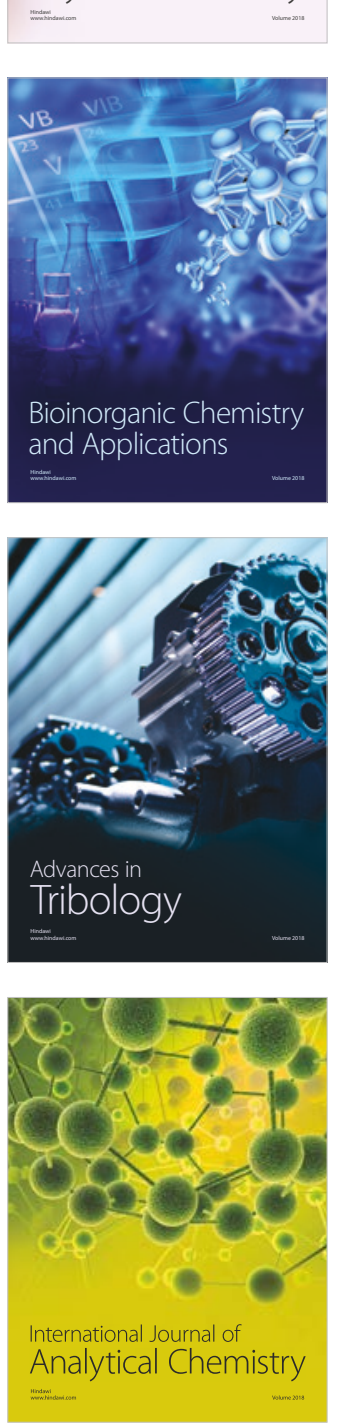

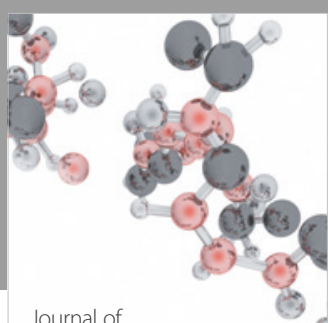

Analytical Methods

in Chemistry

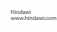

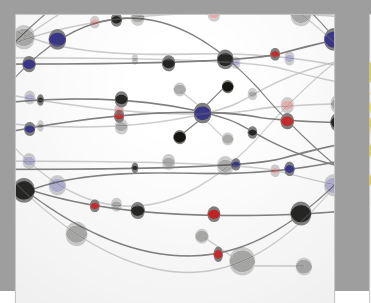

The Scientific World Journal

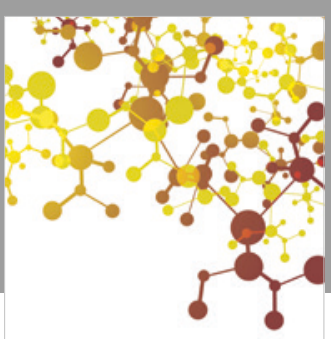

Journal of

Applied Chemistry
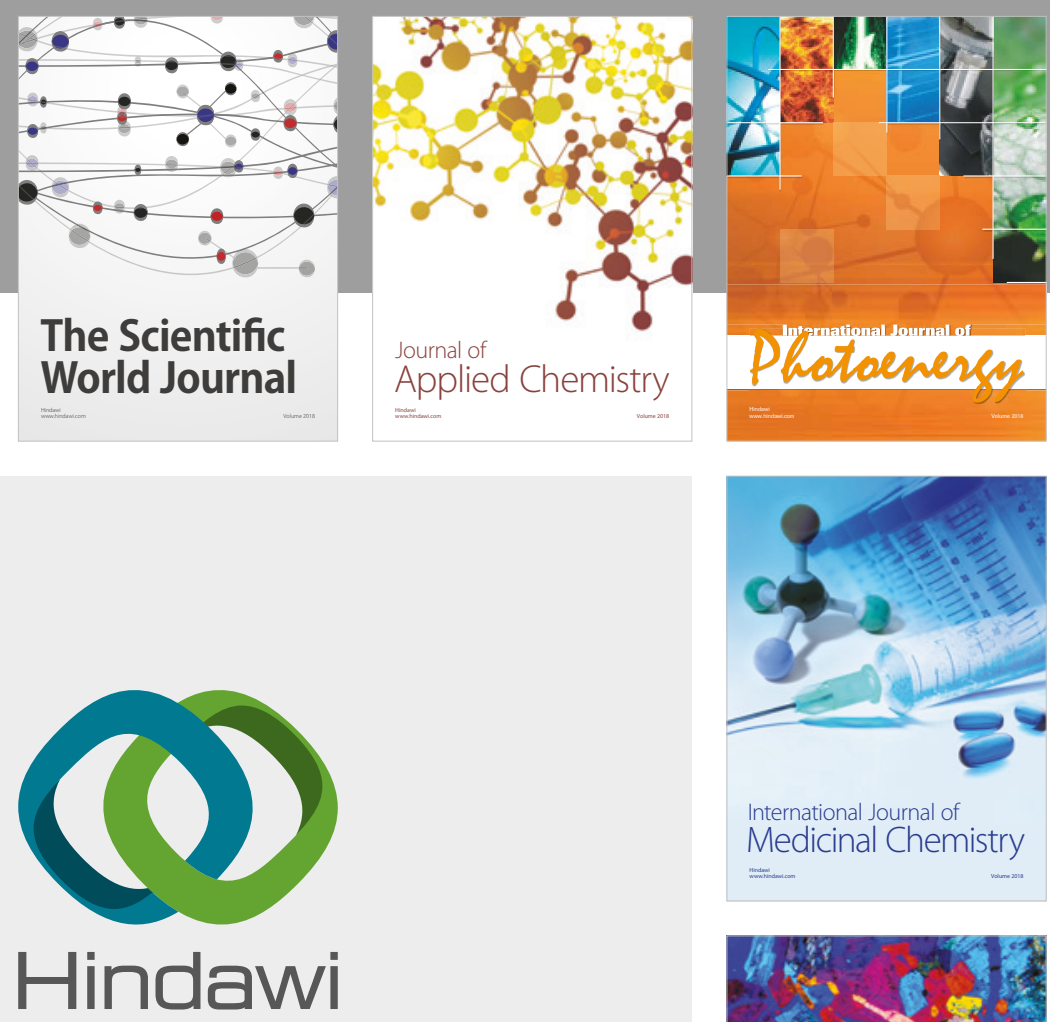

Submit your manuscripts at

www.hindawi.com
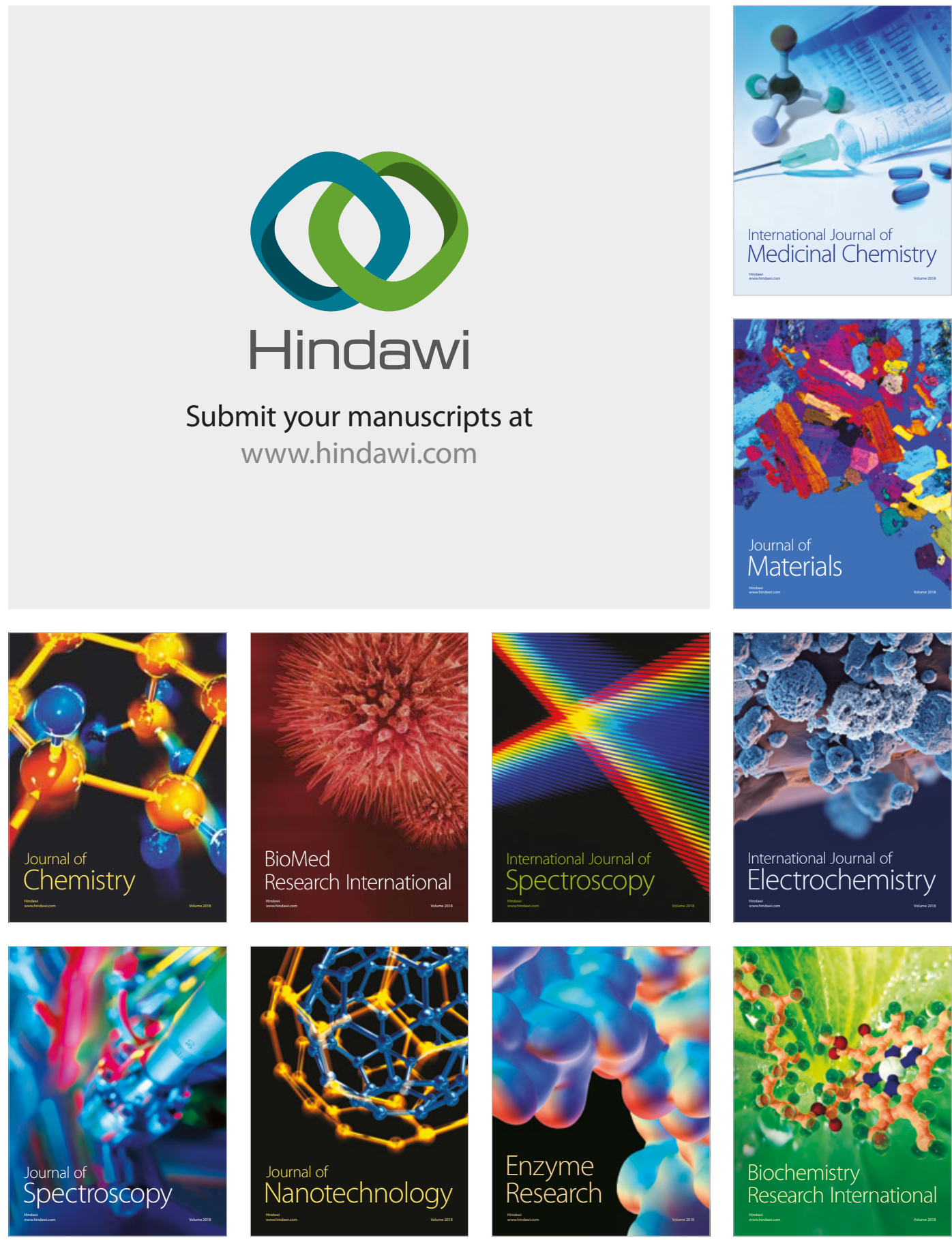
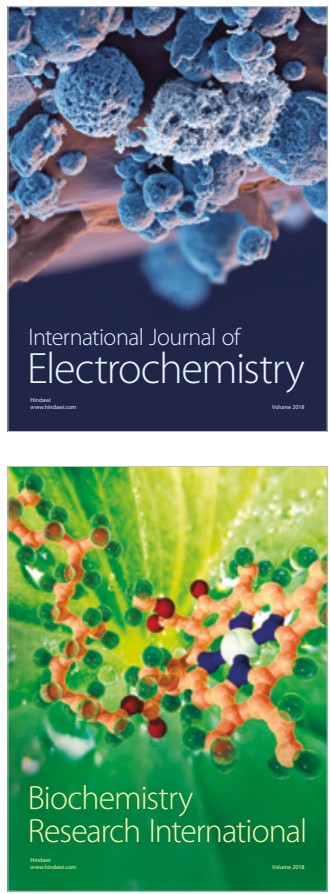